Prime Archives in Immunology: $2^{\text {nd }}$ Edition

Book Chapter

\title{
Crotalus Durissus Ruruima: Current Knowledge on Natural History, Medical Importance, and Clinical Toxinology
}

Manuela B Pucca ${ }^{1}$, Paulo Sérgio Bernarde ${ }^{2}$, Anderson Maciel Rocha $^{3}$, Patrik F Viana ${ }^{4}$, Raimundo Erasmo Souza Farias ${ }^{4}$, Felipe A Cerni ${ }^{1,5}$, Isadora S Oliveira ${ }^{5}$, Isabela G Ferreira ${ }^{5}$, Eliseu A Sandri ${ }^{6}$, Jacqueline Sachett ${ }^{7,8}$, Fan Hui Wen ${ }^{9}$, Vanderson Sampaio $^{10}$, Andreas H Laustsen ${ }^{11}$, Marco A Sartim ${ }^{10,12}$ and Wuelton M Monteiro ${ }^{7,10 *}$

${ }^{1}$ Medical School, Federal University of Roraima, Brazil

${ }^{2}$ Laboratório de Herpetologia, Centro Multidisciplinar, Universidade Federal do Acre, Brazil

${ }^{3}$ Biology Department, Cathedral Faculty of Higher Education, Brazil

${ }^{4}$ National Institute of Amazonian Research, Biodiversity Coordination, Laboratory of Animal Genetics, Brazil

${ }^{5}$ Department of BioMolecular Sciences, School of Pharmaceutical Sciences of Ribeirão Preto, University of São Paulo, Brazil

${ }^{6}$ Insikiram Institute of Indigenous Higher Studies, Federal University of Roraima, Brazil

${ }^{7}$ Department of Medicine and Nursing, School of Health Sciences, Amazonas State University, Brazil

${ }^{8}$ Department of Teaching and Research, Alfredo da Matta Foundation, Brazil

${ }^{9}$ Antivenom Production Section, Butantan Institute, Brazil

${ }^{10}$ Department of Teaching and Research, Dr. Heitor Vieira Dourado Tropical Medicine Foundation, Brazil

${ }^{11}$ Department of Biotechnology and Biomedicine, Technical University of Denmark, Denmark

${ }^{12}$ Institute of Biological Sciences, Amazonas Federal University, Brazil 
Prime Archives in Immunology: $2^{\text {nd }}$ Edition

*Corresponding Authors: Manuela B Pucca, Medical School, Federal University of Roraima, Boa Vista, Brazil

Wuelton M Monteiro, Department of Medicine and Nursing, School of Health Sciences, Amazonas State University, Manaus, Brazil

\section{Published September 13, 2021}

This Book Chapter is a republication of an article published by Wuelton M Monteiro, et al. at Frontiers in Immunology in June 2021. (Pucca MB, Bernarde PS, Rocha AM, Viana PF, Farias RES, Cerni FA, Oliveira IS, Ferreira IG, Sandri EA, Sachett J, Wen FH, Sampaio V, Laustsen AH, Sartim MA and Monteiro WM (2021) Crotalus Durissus Ruruima: Current Knowledge on Natural History, Medical Importance, and Clinical Toxinology. Front. Immunol. 12:659515. doi: 10.3389/fimmu.2021.659515)

How to cite this book chapter: Manuela B Pucca, Paulo Sérgio Bernarde, Anderson Maciel Rocha, Patrik F Viana, Raimundo Erasmo Souza Farias, Felipe A Cerni, Isadora S Oliveira, Isabela G Ferreira, Eliseu A Sandri, Jacqueline Sachett, Fan Hui Wen, Vanderson Sampaio, Andreas H Laustsen, Marco A Sartim, Wuelton M Monteiro. Crotalus Durissus Ruruima: Current Knowledge on Natural History, Medical Importance, and Clinical Toxinology. In: Ajmal Khan, Ahmed Al-Harrasi, editors. Prime Archives in Immunology: $2^{\text {nd }}$ Edition. Hyderabad, India: Vide Leaf. 2021.

(C) The Author(s) 2021. This article is distributed under the terms of the Creative Commons Attribution 4.0 International License (http://creativecommons.org/licenses/by/4.0/), which permits unrestricted use, distribution, and reproduction in any medium, provided the original work is properly cited.

Author Contributions: MP, $\mathrm{PB}$, and $\mathrm{WM}$ conceived the main idea of this work. AR, PV, RF, IO, IF, and ES conducted the bibliography search. MP, PB, IO, MS, and WM designed and wrote most of this review's topics. VS performed the statistical analysis. FC designed the figures of this review article. JS, FC, $\mathrm{AL}$, and $\mathrm{FW}$ corrected the manuscript and provided important 
contributions during the development of this work. All authors contributed to the article and approved the submitted version.

Funding: We thank Fundação de Amparo à Pesquisa do Estado de São Paulo (FAPESP, São Paulo Research Foundation; scholarships to IO no. 2017/03580-9 and FC no. 2017/14035-1), Conselho Nacional de Desenvolvimento Científico e Tecnológico $(\mathrm{CNPq}$, The National Council for Scientific and Technological Development, scholarship to MP no. 307184/2020-0 and WM n. 309207/2020-7) and the Coordenação de Aperfeiçoamento de Pessoal de Nivel Superior-Brasil (CAPES, Finance Code 001, scholarship to IF). WM acknowledges funding support from Fundação de Amparo à Pesquisa do Estado do Amazonas (PAPAC 005/2019, PRÓ-ESTADO and Posgrad calls). MP (Snakebite Roraima project coordinator) acknowledges funding support from Hamish Ogston Foundation-Global Snakebite Initiative.

Conflict of Interest: The authors declare that the research was conducted in the absence of any commercial or financial relationships that could be construed as a potential conflict of interest.

Acknowledgments: We thank Mr. Cícero Antônio Paula Barros, head of the Division of Attention to Indigenous Health, of the Special Indigenous Health District-East of Roraima.

\section{Abstract}

Crotalus durissus ruruima is a rattlesnake subspecies mainly found in Roraima, the northernmost state of Brazil. Envenomings caused by this subspecies lead to severe clinical manifestations (e.g. respiratory muscle paralysis, rhabdomyolysis, and acute renal failure) that can lead to the victim's death. In this review, we comprehensively describe $C$. $d$. ruruima biology and the challenges this subspecies poses for human health, including morphology, distribution, epidemiology, venom cocktail, clinical envenoming, and the current and future specific treatment of envenomings by this snake. Moreover, this review presents maps of the distribution of the snake subspecies and evidence that this species is responsible 
Prime Archives in Immunology: $2^{\text {nd }}$ Edition

for some of the most severe envenomings in the country and causes the highest lethality rates. Finally, we also discuss the efficacy of the Brazilian horse-derived antivenoms to treat $C . d$. ruruima envenomings in Roraima state.

\section{Keywords}

Crotalus durissus; Crotalus durissus ruruima; Rattlesnake; Snakebite; Envenoming; Venom; Antivenom

\section{Crotalus Durissus Ruruima: Natural History}

The species Crotalus durissus is widely distributed in South America and occurs sporadically from Colombia to Argentina. It includes 11 subspecies $(C . d$. durissus, $C . d$. cascavella, $C . d$. collilineatus, $C . d$. cumanensis, $C d$. marajoensis, $C . d$. maricelae, $C$. d. ruruima, $C . d$. terrificus $C . d$. trigonicus, $C . d$. unicolor and $C . d$. vegrandis) [1]. The highly uneven distribution of $C$. durissus in South America, which includes open habitats to the north and south of the Amazon rainforest as well as open relictual formations, adds considerable interest to phylogeographic studies of this complex species [1]. In Brazil, this rattlesnake species $(C$. durissus) presents six subspecies $(C$. $d$. durissus, $C . \quad d$. cascavella, $C . d$. collilineatus, $C . \quad d$. marajoensis, $C$. $d$. ruruima and $C$. $d$. terrificus) [2]. The subspecies $C$. d. ruruima was described by Hoge in 1966 [3], based on specimens collected at Mount Roraima in Venezuela (Figure 1). Among the six Brazilian rattlesnakes, the $C$. $d$. ruruima is one of the most intriguing subspecies due to its restricted distribution (limited to the northern area of the state of Roraima state in Brazil and southern Venezuela) and the unique biochemical and pharmacological properties of its venom $[5,6]$. 


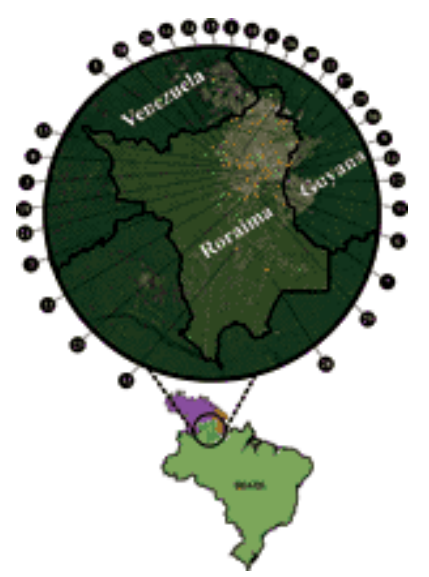

Figure 1: Map with records of Crotalus durissus ruruima in Brazil (BR), Venezuela (VE), and Guyana (GU): 1 - Paulo Camp., Mount Roraima, VE $\left(5^{\circ} 00^{\prime} \mathrm{N} ; 60^{\circ} 52^{\prime} \mathrm{W}\right)(21) ; 2$ - Taiano, Alto Alegre, RR, BR $\left(3^{\circ} 15^{\prime} \mathrm{N} ; 61^{\circ} 04^{\prime} \mathrm{W}\right)$ (21); 3 - Bom Intento Farm, Boa Vista, RR, BR (2॰58'N;6052’W) (14); 4 Pacaraima, RR, BR $\left(4^{\circ} 25^{\prime} \mathrm{N} ; 61^{\circ} 08^{\prime} \mathrm{W}\right)(21) ; 5$ - Maracá Island, RR, BR $\left(03^{\circ} 25^{\prime} \mathrm{N} ; 61^{\circ} 29^{\prime} \mathrm{W}\right)(18) ; 6$ - Boa Vista, RR, BR (02 $\left.{ }^{\circ} 49^{\prime} \mathrm{N} ; 60^{\circ} 39^{\prime} \mathrm{W}\right)(21) ; 7$ $7^{\circ}$ BIS, Boa Vista, RR, BR (02 ${ }^{\circ} 47^{\prime} \mathrm{N}$; 60 $\left.60^{\circ} 1^{\prime} \mathrm{W}\right)(21) ; 8$ - Maloca Mangueira, Alto Alegre, RR, BR $\left(03^{\circ} 18^{\prime} \mathrm{N} ; 61^{\circ} 27^{\prime} \mathrm{W}\right)$ (21); 9 - Bonfim, RR, BR

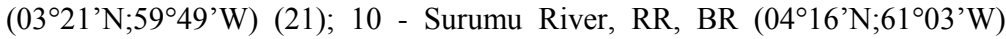

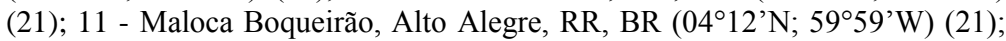
12 - Monte Cristo Farm, Boa Vista, RR, BR (02 $51^{\circ} \mathrm{N}$; 60 $42^{\circ}$ 'W) (21); 13 Salvamento Farm, Alto Alegre, RR, BR $\left(03^{\circ} 20^{\prime} \mathrm{N} ; 61^{\circ} 18^{\prime} \mathrm{W}\right)(21)$; 14 - Igarapé Garrafa, Boa Vista, RR, BR (03 $\left.{ }^{\circ} 12^{\prime} \mathrm{N} ; 60^{\circ} 12^{\prime} \mathrm{W}\right)(21)$; 15 - Sorocaima, RR, BR

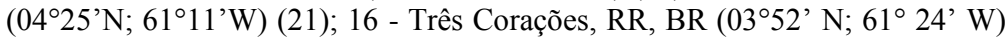
(this study); 17 - Normandia, RR, BR $\left(03^{\circ} 51^{\prime} \mathrm{N}, 59^{\circ} 35^{\prime} \mathrm{W}\right)(14) ; 18$ Tepequém, RR, BR $\left(03^{\circ} 45^{\prime} \mathrm{N}\right.$; 61 $\left.{ }^{\circ} 43^{\prime} \mathrm{W}\right)(21)$; 19 - Campo Alegre, Boa Vista,

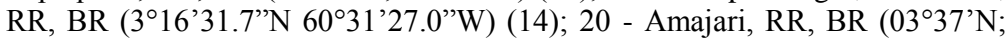
$\left.61^{\circ} 26^{\prime} \mathrm{W}\right)(21) ; 21$ - Passarão, Boa Vista, RR (03¹ $\left.11^{\prime} \mathrm{N} ; 60^{\circ} 35^{\prime} \mathrm{W}\right)(14) ; 22$ Apiaú, Alto Alegre, RR, BR (02³5'N;61 $\left.{ }^{\circ} 18^{\prime} \mathrm{W}\right)(14) ; 23$ - Mucajaí, RR, BR $\left(02^{\circ} 32^{\prime} \mathrm{N} ; 60^{\circ} 55^{\prime} \mathrm{W}\right)(14) ; 24$ - Carimán-Paru, Gran Sabana, VE (0521N; $6142 \mathrm{~W})$ [4]; 25 - Bonfim, RR, BR $\left(03^{\circ} 23^{\prime} \mathrm{N} ; 60^{\circ} 06^{\prime} \mathrm{W}\right)(14) ; 26$ - Uiramutã, RR, BR (460', 60.18'W) (21); 27 - Colônia Coronel Mota em Taiano, Alto Alegre, RR, BR $\left(03{ }^{\circ} 26^{\prime} \mathrm{N}, 61.07^{\prime} \mathrm{W}\right)(21) ; 28$ - Rorainópolis, RR, BR (0'46'27.7’'N 60²4'13.6”W) (21); 29 - Vila Serra Grande, Cantá (this study),

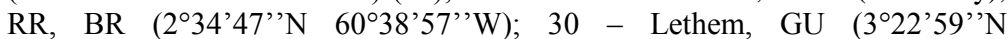
$59^{\circ} 48^{\prime} 17^{\prime}$ 'W) (14); 31 - São Francisco Village, Bonfim, RR, BR $\left(2^{\circ} 48^{\prime} 58^{\prime}\right.$ 'N $\left.60^{\circ} 08^{\prime} 34^{\prime \prime} \mathrm{W}\right)$ (this study); 32 - Viruá National Park - Caracaraí, RR, BR $\left(1^{\circ} 17^{\prime} 39.3^{\prime \prime} \mathrm{N} 61^{\circ} 09^{\prime} 04.6^{\prime} \mathrm{W}\right)(21)$. Georeferencing was made with QGis software and the final figure was prepared using CorelDraw. 


\section{Geographic Distribution}

C. d. ruruima occurs in open areas of savannas (lavrados) in the state of Roraima (Brazil) and on the Mount Roraima slopes and Mount Cariman-Peru in the state of Bolívar (Venezuela) [7] (Figures 2B, C, G, H). It may also occur in adjacent territory of Guyana [7]. In Roraima, $C$. $d$. ruruima has been recorded at the edge of forests near the municipality of Rorainópolis, in Viruá National Park in Caracaraí, in Caubi near the Mucajaí River, Apiaú, Taiano, Fazenda Salvamento, Maloca Boqueirão, Maloca da Mangueira in Alto Alegre, Vila Serra Grande-Cantá, Maracá Island, and to the west of Tepequém in Amajari. In the open regions (working land), it has been recorded close to Boa Vista city on the $7^{\text {th }}$ Infantry base, Bom Intento, Monte Cristo, Passarão, Campo Alegre, Igarapé Garrafa, and Igarapé Carrapato, and follows the open formations from Bonfim to Normandia and the far north of Pacaraima and Uiramutã.

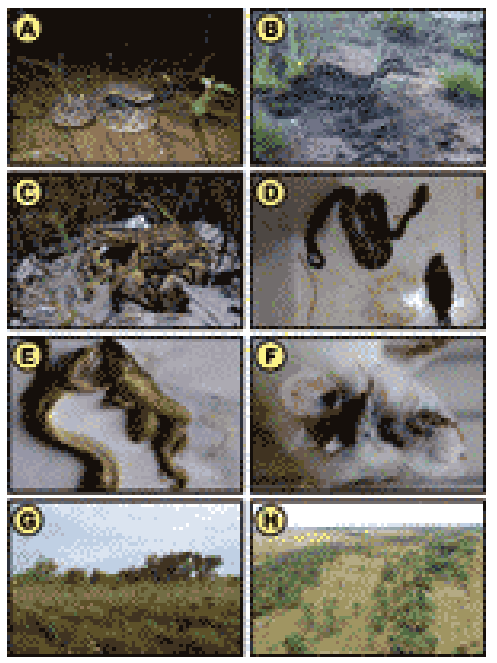

Figure 2 (A-C): Crotalus durissus ruruima; (D) Specimen of C. d. ruruima with rodent found in its stomach contents; (E) Amphibian Leptodactylus macrosternum regurgitated by a juvenile specimen of $C$. $d$. ruruima; (F) Mouse recently bitten by a captive $C$. $d$. ruruima showing massive bleeding; (G) Region of savanna (lavrado) where $C$. $d$. ruruima occurs; (H) Aerial image of the savanna (lavrado) area where $C$. $d$. ruruima occurs. Pictures: Anderson Maciel Rocha. 
C. d. ruruima is restricted to the open areas of the savannas, which is the expected behavior for this species whose life history is related to these plant formations [8]. However, it has already been recorded in the Apiaú region probably by the intense deforestation that provided many open areas that the rattlesnake colonized. This type of population dispersion for $C$. durissus has already been recorded in Rio de Janeiro for subspecies $C$. $d$. terrificus [9].

\section{Taxonomy}

C. $d$. ruruima was recognized by Peter \& Orejas-Miranda (1970) [10] and Cunha \& Nascimento (1980) [11] as a valid taxon. The geographically close subspecies, $C . d$. dryinus and $C . d$. trigonicus, were synonymized with $C$. $d$. ruruima. $C . d$. trigonicus, described by Harris \& Simmons (1978) [12], was synonymized with $C$. $d$. dryinus by Abuys (1987) [13] and subsequently, following the recommendations of Cunha and Nascimento (1980) [11], with C. d. ruruima [14]. Vanzolini \& Caleffo (2002) [8] examined a paratype of $C$. d. dryinus and agreed with Rubio (1998) [14]. Campbell and Lamar in 2004 [7] considered the validity of $C . d$. trigonicus questionable. Costa and Bérnils (2018) did not consider $C$. $d$. trigonicus, and indicated only $C$. d. ruruima for Roraima [2].

\section{Morphology}

The name of the genus Crotalus derives from the Greek word "Krotalon", which means "rattle" or "castanets" in reference to the characteristic appendix at the end of the tail of these snakes [7] (Figure 2A). The rattlesnake belongs to the Viperidae family and Crotalinae subfamily, which is characterized by presenting species with a loreal pit, vertical pupils and keeled dorsal scales [7]. Similar to the other subspecies of $C$. durissus, $C$. d. ruruima has a distinct pair of dark stripes on the neck and a triangular head, which is distinguishable from the neck [7].

C. d. ruruima presents 167-170 ventral scales in males and 174177 in females, and 25-29 subcaudal scales in males and 21-23 in females [3]. In relation to the coloring pattern, the 
paravertebral bands are distinctly marked with white and lighter scales in the center, with the same light center pattern and white outer edges in the head markings [3]. The dorsal diamonds are less contrasted than in $C$. $d$. durissus and sharply surrounded with white, thus approaching the pattern of the specimens of $C$. d. terrificus from the southern end of Brazil. Some specimens have a tendency to have the obliterated pattern of $C . d$. vegrandis.

\section{Size}

The total body length of $C$. $d$. ruruima varies between $315 \mathrm{~mm}$ and $1345 \mathrm{~mm}$, and the average length is $839 \mathrm{~mm} \mathrm{[15].} \mathrm{The}$ smallest male and female presented $368 \mathrm{~mm}$ and $315 \mathrm{~mm}$, respectively, and the largest male and female presented $1250.9 \mathrm{~mm}$ and $1115 \mathrm{~mm}$, respectively [15]. Female specimens tend to be slightly larger, presenting a mean rostro-cloacal length of $630.9 \mathrm{~mm}(\mathrm{n}=22)$, while males presented $627.3 \mathrm{~mm}(\mathrm{n}=41)$ [15]. However, sexual dimorphism was not statistically evident in $C . d$. ruruima; thus the analysis of a greater number of specimens is necessary for a better understanding of possible differences in body length [15]. Generally, in species in which male individuals are larger than female, male-to-female combat occurs [16], and this behavior has already been witnessed in populations of $C$. durissus in southeastern Brazil $[17,18]$.

\section{Habitat and Activity}

Rattlesnakes of the species $C$. durissus are characteristic of open areas (savannas), while it can also occur in areas that have been altered by human activity (pastures and crops) and forest edges $[9,15,19-23]$. In Roraima, this snake is present in the open areas of savannas, woods edges, areas modified by the crop plantings (e.g. corn and soybean), and acacia (Acacia sp.) plantations and pastures $[15,19,22]$.

The rattlesnakes present greater activity during the night twilight period, and are relatively inactive at the beginning of the day (6 to $8 \mathrm{am}$ ), at this time usually going from areas such as firebreaks to their nests [15]. During the afternoon, they usually do not 
present activity; thus, a large part of the specimens are observed in this period inside their burrows [15]. During the twilight-night period, these rattlesnakes present greater activity between $7 \mathrm{pm}$ and midnight, with their activity peak between $9 \mathrm{pm}$ and $10 \mathrm{pm}$ [15].

When they are not hunting during the day, they remain inside their burrows and among grasses and shrubs [15], probably because these microhabitats favor thermoregulation and also contribute to the protection from possible predators [20]. In this situation, where the snake is partially covered by vegetation, its visual detection becomes more difficult [24]. Thermoregulation constitutes the main diurnal activity of nocturnal Viperidae snakes [20,24], which may explain most cases of snakebite in Roraima state, since this period is also that of human activity in the area $[25,26]$.

\section{Diet and Foraging Activity}

C. durissus is terrestrial and hunts mainly by waiting for rodents [20,21,27] (Figure 2F). Small mammals, mainly rodents, make up most of the diet of $C$. durissus in the southeastern [27,28] and central regions [29] of Brazil, though lizards (Ameiva ameiva) are also consumed in a smaller proportion. Birds have also been recorded in the diet of northeastern populations [30] (Figure 2D). Indeed, rodents were the main findings in the stomach contents of $C . d$. ruruima and, less frequently, lizards (Tropidurus hispidus) [15]. Unlike other populations of C. durissus, anurans (Leptodactylus macrosternum) were found in $C$. $d$. ruruima stomachs [31] (Figure 2E), which may be related to differences observed by some authors [6] in the venom of this subspecies.

In relation to the hunting strategy, just as in the populations of other subspecies [20,23], C. d. ruruima hunts by waiting on the ground, seeking preys that exhibit surface activity (rodents, lizards e.g., $T$. hispidus and the amphibians e.g., $L$. macrosternum) [15]. In the burrows where they usually shelter, there have been cases in which 5 or 7 rattlesnakes were found occupying the same burrow [15]. 
Prime Archives in Immunology: $2^{\text {nd }}$ Edition

\section{Seasonality}

During the year, $C$. $d$. ruruima shows greater activity from August to February [15], coinciding with warmer and drier days, which have an average temperature of $27{ }^{\circ} \mathrm{C}$ and average humidity of $71.2 \%$.

\section{Reproduction}

C. durissus is a viviparous species, giving birth to an average of 11 young in southeastern Brazil and between 12 and 33 in northeastern Brazil [32]. The populations of the southeast present long vitellogenesis, beginning in March, with gestation between October and January and the birth of the offspring between January and March [33,34]. Male individuals can perform combat ritual $[17,18]$.

There is little information regarding aspects of reproduction of C. $d$. ruruima [15]. Males are more active throughout the year with peaks in the months of August to November, while females are more frequent in the months of December to the end of January [15]. Juveniles are more frequent during the months of March to May [15], during the rainy period in Roraima (March to June) [35], which probably corresponds to the birth period in offspring. Two pregnant females were recorded during the month of January, one has the total body length of $580 \mathrm{~nm}$ with seven embryos and the other of $730 \mathrm{~mm}$ with nine.

\section{Defensive Behavior}

When a human approaches, the rattlesnake (C. durissus) most often flees but may turn the head and anterior region of the body in the direction of the observer, while shaking the rattle of the tail and curling itself up [21]. Usually, this snake only shakes its rattle when a person comes very close to it (about a meter or less) [21]. Sawaya et al. also studied the defensive behavior of $C$. durissus in the Cerrado area of southeastern Brazil. When handled, it was observed that this snake can shake the rattle of the tail, strike a bite, perform cloacal discharge, open its mouth, struggle, bite, squirt liquid from the cloacal gland in the form of 
jets, and flatten and rotate the body. The secretion from the cloacal gland of $C$. durissus has a strong smell and can cause nausea and burning in the mouth and eyes, indicating that this can be an important defensive tactic against predators [21].

\section{Genetics}

Several molecular analyses, which included different lineages of C. durissus, have generated strong support for monophyly. This includes the lineages of $C$. durissus, $C$. simus, C. tzabcan (southern lineages), and $C$. culminatus, together with two endemic species recently described for Central America: $C$. mictlantecuhtli and C. ehecatl (northern lineages) [1,36-40].

All subspecies of $C$. durissus that occur in Brazil are sister groups to $C$. $d$. vergrandis and $C$. $d$. cumanensis from Venezuela [40]. However, $C . d$. ruruima, together with $C . d$. durissus from Guyana (previously assigned as $C . \quad d$. dryinas) form an arrangement clearly separated from the other subspecies found in Brazil. Furthermore, comparative genomic hybridization involving ancient and advanced lineages of snakes has shown that $C . d$. ruruima and $C . d$. terrificus (Brazilian subspecies) possess different landscapes of repetitive sequences in their genomes, that are likely associated with particular differentiation processes at species level [41]. This highlights that the real diversity of the Neotropical rattlesnake complex is currently underestimated and it is yet to be fully investigated. As such, this would require comparative analyses encompassing all extant subspecies of South American C. durissus lineages.

\section{Crotalus Durissus Ruruima: Venom Composition}

Snake venomics enables the qualitative and quantitative understanding of venoms of different species [42]. There are few studies comparing the venomics of Brazilian rattlesnake subspecies $[5,43,44]$. Interestingly, while originated from the same species (i.e. C. durissus), the Brazilian rattlesnake subspecies present significant differences in venom composition (Table 1). Venom of $C$. d. ruruima presents a great variability, 
with repercussions even in the color, what made the first researchers of this subspecies'venom to classify it in "white" and "yellow" venom [49], which was also observed in C. d. terrificus and $C$. viridis helleri venoms [50,51]. The yellow color of venoms is closely related to the presence of L-amino acid oxidases (LAAOs) [52], which will be discussed later. In this section, the main identified and/or isolated protein classes from C. d. ruruima venom are explored.

Table 1: Venomic comparison of Brazilian Crotalus durissus subspecies.

\begin{tabular}{|c|c|c|c|c|c|c|c|c|c|c|c|c|}
\hline \multirow[t]{2}{*}{ C. durissus } & \multirow[t]{2}{*}{ Crotoxin } & \multirow[t]{2}{*}{ SvSP } & \multirow[t]{2}{*}{ CTL } & \multicolumn{4}{|c|}{ SVMP } & \multirow[t]{2}{*}{ Crotamine } & \multirow[t]{2}{*}{ LAAO } & \multirow[t]{2}{*}{ BIP } & \multirow[t]{2}{*}{ Others } & \multirow[t]{2}{*}{ Ref. } \\
\hline & & & & 1 & " & III & IV & & & & & \\
\hline runuma & 82.7 & 8.1 & 4.3 & - & - & 2.9 & - & 1.5 & $<0.5$ & $<0.1$ & - & (5) \\
\hline cascavella & 72.5 & 1.2 & $<0.1$ & - & - & $<0.1$ & - & - & $<0.1$ & - & 20.3 & (44) \\
\hline collineatus & 67.4 & 1.9 & $<0.1$ & - & - & 0.4 & - & 20.8 & 0.5 & - & 13.8 & (44) \\
\hline durissus & & & & & & & NR & & & & & \\
\hline marajoensis & & & & & & & NR & & & & & \\
\hline terrificus & $48.5-82.7$ & $0.7-25.3$ & $<0.1-2.7$ & & & -5.5 & & $1-19$ & $0.6-4.5$ & 1.8 & $0.5-22.3$ & $(5,45-48)$ \\
\hline
\end{tabular}

\section{Crotoxin (CTX)}

One of the most abundant protein family in $C$. durissus snake venoms is the CTX family $[44,45,53]$. Crotoxin is a heterodimer protein composed of a complex of a basic subunit named phospholipase $\mathrm{A}_{2}\left(\mathrm{PLA}_{2}\right)$ and a non-toxic acidic subunit, crotapotin, which prevents the $\mathrm{PLA}_{2}$ binding in to non-specific sites [54-56]. Among subspecies CTXs' abundance varies from 48.5 to $82.7 \%$ of total venom composition, found more abundant in $C$. $d$. ruruima venom (Table 1) [5]. Crotoxin-rich venoms from Neotropical Crotalus subspecies are classified into type II phenotype, characterized by a high lethality [57]. CTX is responsible for neurotoxicity and myotoxicity, both important events on pathophysiology [5,58-60]. Studies have also brought novel perspectives for CTX as a possible pharmacological strategy due to its anti-inflammatory/immunosuppressive, antitumoral, and microbicidal effects [61-63].

\section{Phospholipases $\mathrm{A}_{2}\left(\mathrm{PLA}_{2} \mathrm{~s}\right)$}

Snake venom $\mathrm{PLA}_{2} \mathrm{~S}$ constitute a puzzling group of molecules since, despite having a similar three-dimensional structure and highly conserved molecular regions, display a plethora of pharmacological activities such as myotoxic, neurotoxic, 
Prime Archives in Immunology: $2^{\text {nd }}$ Edition

anticoagulant, hypotensive, hemolytic, platelet aggregation inhibition, bactericidal, and pro-inflammatory activities [64].

Secretory $\mathrm{PLA}_{2} \mathrm{~S}$ occur in a large variety of venoms (e.g. snakes, arthropods, and mollusks), being able to cleave the $s n-2$ acyl bond of glycerophospholipids, releasing free fatty acids and lyso-phospholipids [65]. Several studies have shown that $C . d$. ruruima venoms contains various isoforms of $\mathrm{PLA}_{2}$ with distinct functions [6,66-68]. Cdr-12 and Cdr-13 are two isoforms that were isolated from $C$. $d$. ruruima snake venom. They present high content of Lys, Tyr, Gly, Arg, and 14 half-Cys residues, typical of a basic $\mathrm{PLA}_{2}$ and show high homology to other D49 $\mathrm{PLA}_{2} \mathrm{~s}$ isolated from venoms of crotalic snakes [66].

Also, the crotoxin-like toxins were capable to induce myonecrosis and edema in mice, and a potent blockade of neuromuscular transmission in chicken biventer cervicis preparation [66]. Cavalcante and colleagues (2015) also observed that a crotoxin isolated from $C$. d. ruruima "white" venom was capable to induce a neuromuscular blockade of indirectly evoked twitches of mice phrenic-diaphragm preparations [68].

Another $\mathrm{PLA}_{2}$ isolated from $C$. $d$. ruruima venom is $\mathrm{PLA}_{2} \mathrm{~A}$, a calcium dependent enzyme which shows antibacterial activity [67]. The most recent $\mathrm{PLA}_{2}$ isolated from $C$. $d$. ruruima is $\mathrm{CBr}$ (basic crotoxin), which presents its 20 amino-terminal residues identical to $\mathrm{CB} 1$ from $C$. $d$. terrificus venom. The $\mathrm{CBr}$ along with the whole venom were able to activate macrophages with focus on the formation of lipids droplets and synthesis of lipid mediators, suggesting its role on the production of inflammatory mediators during envenomings [6]. Moreover, these $\mathrm{PLA}_{2} \mathrm{~s}$ could be responsible to potentiate toxicity of venoms, according to the synergism phenomenon [69].

\section{Snake Venom Serine Proteases (SVSPs)}

SVSPs comprise a group of extensively studied enzymes, widely found in the venom of terrestrial snakes from Viperidae, Elapidae, and Crotalidae families [70]. SVSPs are catalytically 
Prime Archives in Immunology: $2^{\text {nd }}$ Edition

active proteins able to degrade fibrinogen [71], resulting in several biological effects such as hemorrhagic, procoagulant, anticoagulant, platelet activation, and bradykinin-release [72].

Based on their functions, the procoagulant snake venom proteases are classified as factors I (snake venom thrombin-like enzymes, SVTLEs), V, VII and X, and groups C and D prothrombin activators [73]. SVTLEs are the prevalent class of SVSPs from Viperidae venoms and present similar activities to human thrombin [74,75]. The SVTLEs are considered multifunctional toxins due to their broad substrate specificity and can act on different biological systems of the preys or the victims. Therefore, the investigation of the intrinsic pathways involved in the variety of biological activities of these molecules may contribute to expanding their potential applications [76].

Although $C$. $d$. ruruima venom presents SVSPs (8.1\%) [5], these enzyme classes have never been isolated from this venom, unlike from C. d. terrificus (0.7-25.3\%; Table 1) [5,45-48], from which two SVSPs have been isolated, gyroxin and CdtSP2, presenting important roles in coagulation disturbances, neurotoxicity, and inflammation [77-79]. Studies have also shown potential therapeutic use of SVSPs from $C$. durissus subspecies, such as the use for fibrin sealant in the treatment of dermatological ulcers [80]. Also, an SVSP from $C$. $d$. collilineatus venom $(1,9 \%)[44,81]$ was recently shown to modulate ion channels (hEAG1, Kv10.1, KCNH1), helping to understand and reveal the complex and pluripotent pharmacology of SVTLEs, and also to open perspectives in terms of applicability particularly in the field of oncology due to its action on the oncogenic ether-a-gogo 1 voltage-gated potassium channel [70].

\section{C-Type Lectin-Like Proteins (CTLs)}

C. $d$. ruruima is the Brazilian subspecies that presents the highest abundance of CTLs (4.3\%) [5], while the others subspecies present lower proportions in their venoms $(<2.7 \%)[5,45-48]$. Snake venoms CTLs are heterodimeric proteins, composed of two homologous subunits $\alpha$ and $\beta$ (with 14-15 $\mathrm{kDa}$ and 13-14 $\mathrm{kDa}$, respectively), which can be arranged in oligomeric 
complexes $[82,83]$. They show low primary sequence similarities to venom sugar-binding lectins, with no ability to interact with glycans. However, CTLs show an indiscriminate ligand spectrum, targeting clotting factors and several receptors on platelets, endothelial cells, and immune cells. This results in a wide range of pharmacological activities, acting in hemostasis and inflammation [84]. There are no studies that disclose the isolation and characterization of this protein class from $C$. $d$. ruruima. Nonetheless, others CTLs have been described in $C$. durissus venoms. Convulxin, isolated from $C$. $d$. terrificus consists of the most studied CTLs, acting as a plateletaggregating agonist that acts on the p62/GPVI collagen receptor in platelet surface [85]. Other CTL is crotacetin, a convulxinhomologue toxin isolated from $C . d$. terrificus, $C . d$. cascavella, and $C . d$. collilineatus venoms with platelet aggregating and antibacterial activity [86].

\section{Snake Venom Metalloproteases (SVMPs)}

SVMPs comprise a group of metal-dependent proteases, playing a critical role in the proteolytic and biological activities of the venom [87]. Zinc-dependent SVMPs belong to the metzincin family, which has a zinc-binding domain in common and structures very similar to each other. The zinc-binding site of this family has the amino acid sequence that is common to all subfamilies [88].

Metalloproteases are classified into three classes (PI, PII, and PIII) according to the organization of their multi-domains, considering the presence or absence of non-proteolytic domains observed in mRNA transcripts and in isolated proteins from snake venom [89]. The PI-SVMPs are composed only of a metalloprotease domain. The PII-SVMPs have a metalloprotease domain followed by a disintegrin domain, which are often separated by a post-translational proteolytic cleavage. Both proteolytic products are stable [89]. Finally, the PIII-SVMPs have a cysteine-rich domain (Cys-rich), in addition to metalloprotease and disintegrin-like (dis-like) domains. The PIII is subdivided into subclasses (PIIIa, PIIIb, PIIIc, and PIIId), reflecting the potential proteolytic processing and formation of 
Prime Archives in Immunology: $2^{\text {nd }}$ Edition

dimeric structures, for which PIII has an additional lectin-like domain $[89,90]$.

According to the venomic approach, $C$. $d$. ruruima presents only PIII-SVMP in its venom composition (2.9\%) [5], as well as $C . d$. cascavella $(<0.1 \%)$ and $C$. d. collilineatus $(0.4 \%)$ [44], although the latter also presents disintegrins [44,53], while $C$. d. terrificus presents varied proportions of the SVMPs group (0.09-5.5\%; Table 1) [5,45-48]. Although SVMPs from $C$. durissus subspecies are poorly studied, this group of toxins from Crotalus spp. from North and Central Americas are more abundant and have been widely investigated. These studies have shown hemostatic effects such as fibrino(geno)lytic and inhibition of platelet aggregation activities as well as local hemorrhage caused by degradation of the capillary basement membrane and muscle damage with lower regeneration [91-93]. As $C$. d. ruruima venom composition differs from other more prevalent $C$. durissus subspecies envenomings, an antivenom based on oligoclonal mixtures of antibodies could be a strategy to improve treatment.

\section{Crotamine}

Crotamine, which may or may not be present, is one of the main components of rattlesnake venoms. This particularity indicates a Mendelian character of the toxin, since its frequency increases according to the east-west and north-south axes in Brazilian territory [44,94]. Although $C$. d. ruruima venom can present crotamine in their venom cocktail, its abundance is very low $(1.5 \%)$ as shown in preliminary results [5] when compared to $C$. d. collilineatus venom (20.8\%) [44]. Crotamine has an evident myotoxic action during envenomings, which was demonstrated through increased levels of creatine phosphokinase (CK) in vivo $[53,58,95]$, as well as neuromuscular blocking effects [96] and hemostasis modulation $[79,97]$.

\section{Bradykinin-Inhibitory Peptide (BIP)}

C. $d$. ruruima and $C$. $d$. terrificus are the only Brazilian rattlesnakes presenting BIP, even in a low proportion $(<1.8 \%)$ 
[5]. This molecule was found in other Crotalinae venoms (e.g. $C$. viridis viridis, Lachesis muta, and Agkistrodon bilineatus venoms), which present a fully conserved primary structure, suggesting a conserved biological role for this toxin [98]. BIPs present antagonistic effects on the vasodilatation induced by bradykinin at bradykinin receptor type 2 (B2 receptors), which are expressed in vascular endothelial and smooth muscle cells [98,99], resulting in vasoconstriction effects by disrupting the functioning of the cardiovascular system, thus also contributing to clinical effects of envenomings [98].

\section{L-Amino Acid Oxidases From Snake Venoms (SV- LAAOs)}

SV-LAAOs are widely distributed in venomous snake families of Viperidae, Crotalidae, and Elapidae [52]. LAAOs are flavoenzymes that catalyze the stereospecific oxidative deamination of an L-amino acid substrate, producing $\alpha$-keto acid, ammonia, and hydrogen peroxide $\left(\mathrm{H}_{2} \mathrm{O}_{2}\right)$ [100-102]. With a molecular mass of around 110-150 kDa under non-denaturating conditions, SV-LAAOs are homodimeric glycoproteins linked to flavin adenine dinucleotide (FAD) $[103,104]$. As a prosthetic group of LAAOs, FAD has riboflavin, which characterizes the yellow color of venoms [52].

An interesting aspect of $C . d$. ruruima venom concerns its color, presenting a "white" and "yellow" variation with particular biological activities [49]. The proteome analysis performed by Calvete and colleagues from $C$. $d$. ruruima was performed with a pool of "white" venom, and showed a low abundance of LAAO $(<1 \%)$ [5]. In other, C. durissus subspecies venoms, LAAOs are also present in low abundance [44], with a highest concentration of $4.5 \%$ found in a C. d. terrificus sample (Table 1) [5,45-48]. LAAO's physiological role is still unknown; it is speculated that they may be related to venom conservation and stabilization of the venom glands, due to their antibacterial properties [102]. LAAOs have been isolated from $C$. durissus venoms, showing hemolytic activity, induced plasma clot and platelet aggregation [105-107]. Many of these could be related, at least in part, with $\mathrm{H}_{2} \mathrm{O}_{2}$ produced during the chemical reaction catalyzed by 
Prime Archives in Immunology: $2^{\text {nd }}$ Edition

LAAOs, contributing to envenoming toxicity, due to oxidative stress $[108,109]$.

\section{C. d. Ruruima Specific Features}

Although the main rattlesnake toxins were described in $C . d$. ruruima venom using proteomics [5], many toxins encountered in other Brazilian C. durissus subspecies (e.g. disintegrins, hyaluronidases, growth factors, nucleases, and nucleotidases), which are also determinants for the toxicity of venoms, have not been described for this subspecies [5,43-46,53,110,111]. However, we do not exclude the possibility of $C$. $d$. ruruima presenting other compounds. Dos-Santos and colleagues evidenced individual venom variations between six $C . d$. ruruima snakes: 1) the toxicity of white venoms was higher than yellow venoms; 2) $\mathrm{PLA}_{2}$ activity also varied, being higher in yellow venom; 3 ) only one white venom showed hemorrhagic activity; 4) myotoxicity degree and edematogenic activity varied between venoms; and 5) coagulant activity in human plasma or bovine fibrinogen also varied between tested venoms [112]. Another study with white and yellow venoms from $C . d$. ruruima demonstrated that they have similar lethality and coagulant activity, while presenting small differences regarding proteolytic, hemorrhagic, and necrotic activities [49]. Cavalcante and colleagues (2015) also observed that $C$. d. ruruima "white" venom was capable of inducing a neuromuscular blockade of indirectly evoked twitches of mice phrenic-diaphragm preparations [68].

$C$. $d$. ruruima venom is the one with the highest abundance of crotoxin. Based on the high proportion of crotoxin, $C$. $d$. ruruima venom could be considered the most toxic Brazilian rattlesnake venom, since its "lethal neurotoxicity coefficient" (LNC) is higher than the other Brazilian rattlesnakes already studied $[5,44]$. This coefficient is determined through the ratio of average venom $\mathrm{LD}_{50}$ and the neurotoxins concentration (crotoxin and crotamine) [5]. This fact could justify the severe cases of envenoming and lethality caused by $C$. $d$. ruruima snakes [26,59]. 
Prime Archives in Immunology: $2^{\text {nd }}$ Edition

\section{Human Envenomations Caused by $C . d$. Ruruima \\ Epidemiological Aspects}

In Brazil, snakebites are compulsorily recorded by the Sistema de Informação de Agravos de Notificação (SINAN, Brazilian Notifiable Diseases Surveillance System), based on data report forms used in the investigation and follow-up of cases of envenomings caused by animals. In the state of Roraima, in the extreme north of Brazil, $C$. $d$. ruruima is known to be the unique subspecies of $C$. durissus responsible for the local envenomings. Thus, the description of crotalid envenomings registered in SINAN in this state can provide important information about the epidemiological and clinical features of envenomings by $C$. $d$. ruruima. Of a total of 3,616 snakebites ( 71.3 cases $/ 100,000$ persons/year) reported to SINAN from January 1, 2010, to December 31, 2019, in Roraima, 396 (10.9\%) cases were caused by rattlesnakes, resulting in an incidence rate of 7.8 cases/100,000 people/year.

Spatial distribution of rattlesnake bites across the Brazilian Amazon showed higher incidence in areas of savanna in high altitude areas [113]. In Roraima, the geographic distribution of Crotalus envenoming shows the highest incidence rate in the northernmost municipalities, in the border with the Guyana and Venezuela, namely in the municipalities of Uiramutã and Normandia (Figure 3), coinciding with savannas that occur in mountainous areas in the northern areas of the state. There was a slight variation in the annual incidence rates during the study period. Incidence was higher in 2018 (94 cases; 16.3 per 100,000 inhabitants) and 2017 (54 cases; 10.3 per 100,000) and lower in 2010 (11 cases; 2.4 per 100,000). The seasonality of the cases was modest, with a slight increase in cases from the beginning of the rainy season. 


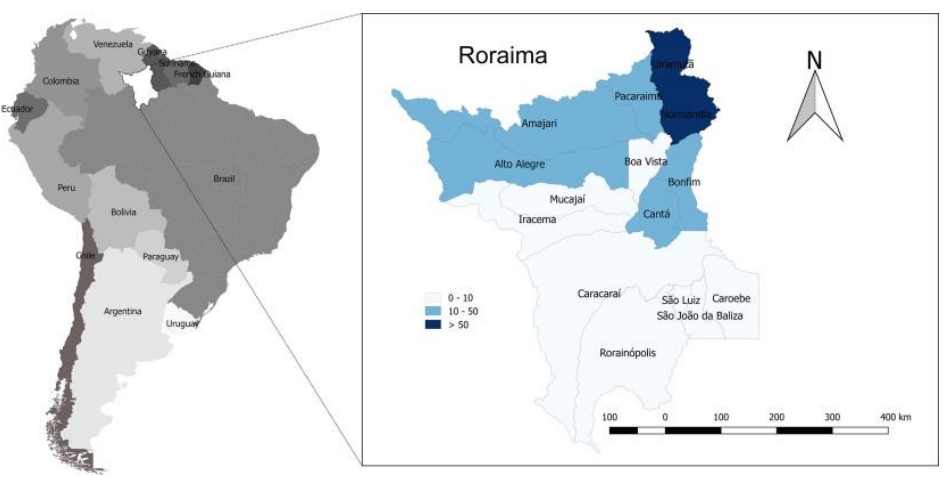

Figure 3: Geographic and temporal distribution of Crotalus durissus ruruima snakebites in the state of Roraima, Brazilian Amazon. Incidence rate per municipality (cases/100,000 inhabitants/year, showing a higher incidence in the north of the state).

Most of the snakebites occurred in males (77.3\%). The most affected age group was between 16 and 45 years old (51.0\%). Strikingly, Amerindians represent $11 \%$ of the Roraima's total population but suffered $64.9 \%$ of reported Crotalus envenomings; this incidence is $\sim 12$ times higher than in the nonAmerindian population. In the Amazon, the distribution of the snakebite burden is disproportional among indigenous and nonAmerindian populations. In the state of Amazonas, the prevalence is 7.5 times higher among Amerindians [114]. Indigenous people's way of life, and their daily subsistence activities, involve daily interaction with snakes, without personal protective equipment, thus increasing the risk of snakebites [114]. Regarding the area of occurrence, $93.0 \%$ were reported in rural areas; $24.3 \%$ of the snakebites were related to work activities. Regarding time elapsed from the bite until medical assistance, $57.0 \%$ of the cases received treatment within the first six hours after the snakebite, $22.7 \%$ within 6-24 hours, and $20.3 \%$ with more than 24 hours after the bite. Among the victims, $14.6 \%$ were illiterate, and $36.1 \%$ had $\leq 4$ years of study. Most of the snakebites occurred in the lower $(85.6 \%)$ and upper limbs (13.1\%) (Table 2). This epidemiological profile confirms small case series previously published in the state of Roraima $[25,26,115]$. Asato and colleagues showed that the C. ruruima envenomings attended to in Boa Vista, the capital of the state of 
Prime Archives in Immunology: $2^{\text {nd }}$ Edition

Roraima, predominantly involved farmers during morning or afternoon work in their fields [26].

Table 2: Epidemiological characteristics of $C$. $d$. ruruima envenomings reported in the state of Roraima, northern Brazilian Amazon, from 2010 to 2019.

\begin{tabular}{|c|c|c|}
\hline Variable (Completeness) & Number & $\%$ \\
\hline \multicolumn{3}{|l|}{$\operatorname{Sex}(n=396 ; 100 \%)$} \\
\hline Male & 306 & 77.3 \\
\hline \multicolumn{3}{|c|}{ Age range, in years $(n=396 ; 100 \%)$} \\
\hline $0-15$ & 113 & 28.5 \\
\hline $16-45$ & 202 & 51.0 \\
\hline $46-60$ & 51 & 12.9 \\
\hline$\geq 61$ & 30 & 7.6 \\
\hline \multicolumn{3}{|l|}{ Ethnicity ( $n=379 ; 95.7 \%)$} \\
\hline White & 10 & 2.6 \\
\hline Black & 13 & 3.4 \\
\hline Asian & 2 & 0.5 \\
\hline Mixed & 108 & 28.4 \\
\hline Amerindian & 246 & 64.9 \\
\hline \multicolumn{3}{|c|}{ Area of occurrence $(n=384 ; 97 \%)$} \\
\hline Rural & 357 & 93.0 \\
\hline Urban & 27 & 7.0 \\
\hline \multicolumn{3}{|c|}{ Work-related ( $n=296 ; 74.7 \%$ ) } \\
\hline Yes & 72 & 24.3 \\
\hline \multicolumn{3}{|c|}{ Education level, years $(n=219 ; 55.3 \%)$} \\
\hline Illiterate & 32 & 14.6 \\
\hline$\leq 4$ & 79 & 36.1 \\
\hline $5-8$ & 49 & 22.4 \\
\hline$>8$ & 59 & 26.9 \\
\hline \multicolumn{3}{|l|}{ Site of the bite $(n=388 ; 98 \%)$} \\
\hline Head & 4 & 1.0 \\
\hline Trunk & 1 & 0.3 \\
\hline Lower limbs & 332 & 85.6 \\
\hline Upper limbs & 51 & 13.1 \\
\hline \multicolumn{3}{|c|}{ Time from bite to medical assistance, hours ( $n=375 ; 94.7 \%)$} \\
\hline$\leq 6$ & 214 & 57.0 \\
\hline$>6-24$ & 85 & 22.7 \\
\hline$>24$ & 76 & 20.3 \\
\hline
\end{tabular}


Prime Archives in Immunology: $2^{\text {nd }}$ Edition

\section{Clinical Aspects and Physiopathology}

There is very little information in the literature on the clinical manifestations of envenomings caused by $C$. $d$. ruruima. However, the few reports suggest some differences in relation to the clinical pictures resulting from different subspecies of $C$. durissus found in South America. The main difference pointed out is the high frequency of inflammatory manifestations at the bite site and coagulopathy $[26,115]$. However, the small number of published cases prevents a more accurate comparison with data from other regions. To explore this review's mentioned hypothesis and to present a more accurate comparison of envenomings caused by different subspecies of $C$. durissus, we analyzed the data gathered by SINAN, from 2010 to 2019, comparing envenomings cases of Crotalus occurring in six regions of the country in which the snake is present (Figure 4). Only country units (states) without subspecies overlap in geographical distribution of six $C$. durissus subspecies, according to the current knowledge [1,2], were selected for comparison, using the group of patients envenomed by $C$. $d$. ruruima (cases from the state of Roraima) as the reference. As the epidemiological characteristics of the cases are different in relation to demographics and access to the health system, the results were statistically adjusted by sex, age, and time until the assistance. Results must be interpreted with caution, since a limitation of this approach is related to the lack of standardization in the clinical management of cases and data collection in different country regions, and the number of cases described for each subspecies differs widely. However, we believe that the broad population coverage allowed the acquisition of valuable information to guide future studies. 

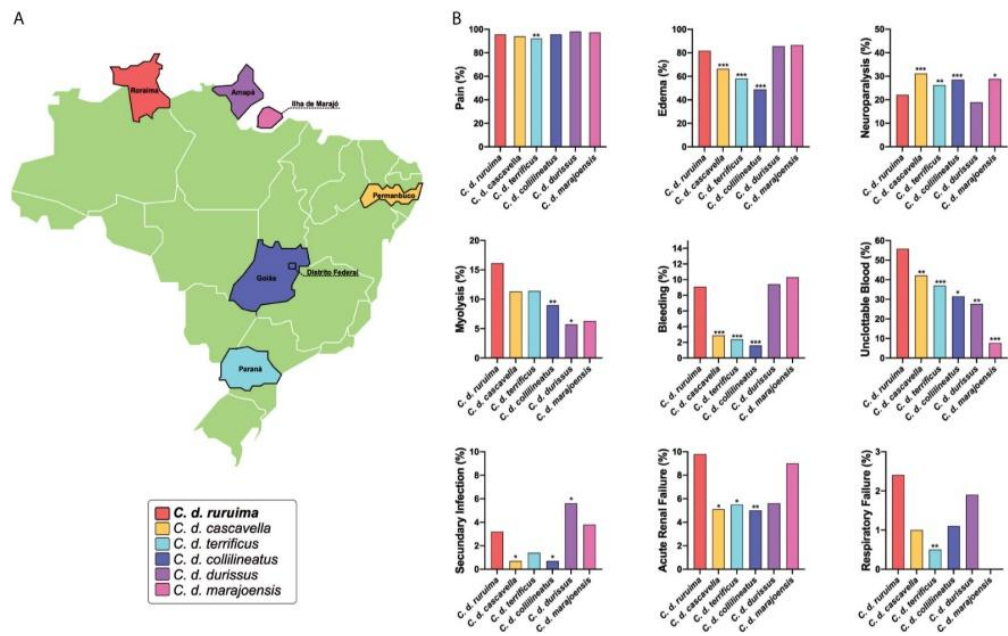

Figure 4: Cross-country comparison of local and systemic manifestations in envenomings caused by different Crotalus durissus subspecies. Data was gathered from the SINAN, from 2010 to 2019. Information was stratified by state, considering the geographic distribution of six $C$. durissus subspecies. (A) Only states without subspecies overlap in geographic distribution were selected. For statistical comparison, X-square or Fisher's tests were performed in STATA software (StataCorp. 2013: Release 13. College Station, TX, USA), using the group of patients envenomed by $C . d$. ruruima as the reference. After the univariable analysis, any difference in the frequency of clinical manifestations between $C$. $d$. ruruima and another subspecies envenoming at a significance level of $p<0.20$ were included in a multivariable analysis, adjusting by age, sex, and time to medical assistance. Statistical significance was considered if $p<0.05$ in the Hosmer-Lemeshow goodness-of-fit test. (B) Only clinical manifestations with any significant difference are presented. Number of patients according $C$. durissus subspecies: $C$. $d$. ruruima $(\mathrm{n}=396), C$. $d$. cascavella $(\mathrm{n}=990), C . d$. terrificus $(\mathrm{n}=1,016), C . d$. collilineatus $(\mathrm{n}=2,093), C$. d. durissus $(\mathrm{n}=54), C$. . marajoensis $(\mathrm{n}=80) ; * p<0.1 ; * * p<0.05 ; * * * p<$ 0.01 .

\section{Bite Site Manifestations}

In general, the authors report that local manifestations are usually discreet during envenomings caused by $C$. durissus, as a result of the low inflammatory activity of the venom [116-118]. The most frequent local manifestation among Crotalus envenomings reported to SINAN was pain, ranging from $92.1 \%$ in $C . d$. terrificus to $98 \%$ in $C . d$. durissus (Figure 4). In C. d. ruruima envenomings, frequency of pain (95.6\%) was 
significantly higher only than $C$. $d$. terrificus (Figure 4). Some studies have shown that pain may be absent in a large proportion of patients in São Paulo, where $C$. d. terrificus is the snake mainly responsible for envenomings [117]. Edema (81.8\%) was also very common in $C$. $d$. ruruima cases, at a higher frequency than observed for $C$. d. cascavella (66.4\%), C. d. terrificus (58\%), and C. d. collilineatus (48.9\%) (Figure 4). Unfortunately, paresthesia is not reported by SINAN but is also a very common manifestation in Crotalus bites. In $C$. $d$. ruruima envenomings, paresthesia frequency ranges from 12.5 to $16.2 \%$ [26,115]. In the state of São Paulo, paresthesia was reported in $47.6 \%$ of the children [117] and 26.1\% [116] of the general cases of Crotalus bites.

Local complications such as secondary infections and compartment syndrome seem to appear at very low frequency in Crotalus bites $[119,120]$. Data from SINAN show that secondary infections frequency ranged from $0.7 \%$ in $C$. $d$. cascavella and $C$. $d$. collilineatus, to $5.6 \%$ in $C$. $d$. durissus. In $C$. d. ruruima envenomings, the frequency of secondary infections (3.2\%) was significantly higher than $C . d$. cascavella and $C$. d. collilineatus, but lower than $C$. $d$. durissus (Figure 4). Necrosis, compartment syndrome, functional loss and amputation were rare, and their frequencies were similar between envenomings caused by different $C$. durissus subspecies.

Local manifestations are commonly associated with the inflammatory properties that venom can trigger once inoculated. Although toxins from $C$. durissus subspecies are known to present low immunogenicity, studies have shown the capacity of venoms and toxins to promote local and systemic inflammatory responses in animal models [78,121,122]. As previously described, C.d. ruruima "yellow" and "white" venom variations are responsible for inducing mouse paw edema [112]. Considering that the venom components crotoxin and serine proteases are found to trigger an inflammatory response [78,122], the higher frequency in local manifestations, such as edema, found in Roraima state could be associated with $C$. $d$. ruruima venom composition, in which the two toxins classes comprise over $90 \%$. Moreover, although the low abundance of 
Prime Archives in Immunology: $2^{\text {nd }}$ Edition

SVMP found in $C$. $d$. ruruima venom can be associated with rare cases of local sequelae, this group of toxins could be an additional factor for local injury as observed for North American Crotalus spp. venoms [93].

\section{Rhabdomyolysis and Acute Renal Failure}

The myotoxic activity is a result of the venom-induced skeletal muscle breakdown, often associated with rhabdomyolysis [123]. In the state of Roraima, dark urine (13.5\%) and myalgia ( 25\%) were reported after $C$. $d$. ruruima envenomings [26,115]. In the state of São Paulo, myalgia and dark urine were detected in 38.6 and $36.1 \%$ of the patients, respectively [118]. In Minas Gerais, myalgia was detected in $29 \%$ and dark urine in $40 \%$ of the patients [124]. In children from the same region, frequencies of myalgia and dark urine were still higher, exceeding $70 \%$ of the patients [116,117]. In the analysis of the SINAN database, rhabdomyolysis was significantly higher in patients bitten by $C$. d. ruruima $(16.1 \%)$ using univariable analysis, compared to all other subspecies. However, after adjusting by sex, age, and time to medical assistance, significant difference remains only for $C$. $d$. collilineatus (Figure 4). The non-standardized collection of these signs and symptoms may prevent accurate comparisons across studies. In $C$. $d$. terrificus, serum CK activity increases early, reaching a peak in the first 24 hours after the bite, remaining above reference levels for more than four days in some patients [116,117]. In envenomings caused by $C$. $d$. terrificus [117,118,124], C. d. collilineatus [124,125], C. d. marajoensis [126], and $C$. d. ruruima [26], CK activity was above normal levels in $\sim 90 \%$ of the patients $[118,124,125]$. Serum activities of lactate dehydrogenase and liver transaminases are also elevated in most cases. Hypocalcemia may occur in patients with intense rhabdomyolysis after $C$. $d$. terrificus bites [116]. Both crotoxin and crotamine are the major myotoxic components within $C$. durissus venoms [96,127]. Moreover, crotoxin exhibits a capacity to spread to distant muscles and induce rhabdomyolysis, due to its systemic distribution ability mediated by the heterodimeric complex formation of the toxin to bind to specific cell targets [128]. C. $d$. ruruima crude venom showed myotoxic activity, as observed for 
increased plasma levels of CK and histopathological analysis of myonecrosis $[49,112]$. Isolated crotoxin from this venom also induced increased plasma levels of CK and LDH not only at intramuscular administration but also intraperitonealy, confirming the systemic effect of CTX [66], Considering the role of crotoxin in muscular damage events and its high abundance in $C$. d. ruruima venom, the high frequency of myonecrosis in patients from Roraima state could be associated with CTX activity.

As a consequence of rhabdomyolysis, a major complication following Crotalus snakebites is acute renal injury [123]. The definitions of acute renal failure vary widely across studies, and this lack of standardization is also a bottleneck for comparisons. In $C . d$. ruruima envenomings, $13.5 \%$ of the patients presented acute renal failure (serum creatinine $>1.5 \mathrm{mg} / \mathrm{dL}$ ) [26]. The frequency of acute renal failure was $18 \%$ in Minas Gerais [124] and 12.9\% in São Paulo [118]. In Central Brazil, 29\% of the patients developed acute renal failure; of those, $24 \%$ required dialysis, and $10 \%$ died [125]. In São Paulo, $20 \%$ of children envenoming developed acute tubular necrosis, and half of them needed hemodialysis [117]. Delay for antivenom treatment [124,125] and CK at admission >2000 U/L [125] were risk factors for acute renal failure development. The effect of age is controversial [124,125]. In a SINAN-based cross-country comparison, the frequency of acute renal failure was significantly higher in $C$. $d$. ruruima envenomings than in $C . d$. cascavella, $C . d$. terrificus, and $C . d$. collilineatus, even after adjustment by age, sex, and time to medical care (Figure 4 ).

Experimental models using $C$. durissus subspecies' venoms and isolated toxins showed important renal alterations, for which several mechanisms are proposed [129-132]. Possibly the most critical concern is the damage to skeletal muscle by the myotoxins crotoxin and crotamine, as discussed above. As the major crotoxin-induced product into the circulation, myoglobin is responsible for inducing renal vasoconstriction, formation of intratubular casts, and the direct toxicity to kidney tubular cells, which can be followed by acute kidney injury (AKI) [133]. $C$. durissus-induced inflammation is another possible mechanism 
associated with kidney function; previous studies have shown that inflammatory mediators released from venom-treated macrophages were responsible for renal disturbances $[134,135]$. Although no studies have been conducted to associate Crotalusinduced renal abnormalities with coagulation disorders, this is an important issue to be considered. As a consequence of intravascular coagulation and hemostatic components consumption observed in $C$. durissus patients [115,136], vascular ischemia due to microthrombi deposition [118] could be responsible for impaired renal functions as observed in similar cases of Bothrops accidents [137].

Among venom components, crotoxin was responsible for significant changes in renal function, followed by serine protease inducing mild alterations and CTL with no effects [129]. Therefore, the high frequency of AKI in $C$. $d$. ruruima patients could be a result of myolisis, coagulation disturbances, and inflammation, also with elevated frequency in patients from Roraima. In contrast, crotoxin as the major venom component can play an important role in these events' physiopathology.

\section{Coagulation Disorders}

Coagulopathy in Crotalus envenomings is attributed to the presence of hemostatically active components in the venom, which can lead to hypofibrinogenemia and unclottable blood [123]. Unclottable blood is observed in most of the Crotalus envenomings in Brazil, but systemic bleeding seems to be less common $[116,118,124,125,138]$. In their case series, Cupo and colleagues did not find hemorrhage or thrombosis in the necroscopic analysis [117]. Bucaretchi and colleagues (2013) report a case of juvenile $C$. $d$. terrificus envenoming that evolved with coagulopathy as the main systemic manifestation, without systemic bleeding [136]. Also, local bleeding persisting on admission is not a common feature in Crotalus envenomings. In Roraima, however, the proportion of the patients presenting to the hospital with bleeding at the bite site ranged from $12.5 \%$ [115] to $24.3 \%$ [26]. In $C$. $d$. ruruima envenomings, unclottable blood was reported in $62.5 \%$ and hypofibrinogenemia in $50 \%$ of the patients [115]. One fatal case of rattlesnake envenoming 
attended in Roraima evolved with increased prothrombin time, severe thrombocytopenia, and macroscopic hematuria [59]. In the patients reported to SINAN-Roraima, clotting time was prolonged in $55.8 \%$, and systemic bleeding was reported in $9.1 \%$ of the patients (Table 3 ). In the cross-country comparison using the SINAN database, blood unclottability was significantly more prevalent in $C$. $d$. ruruima compared to other $C$. durissus subspecies. Furthermore, systemic bleeding was more frequent in $C . d$. ruruima compared to $C . d$. cascavella, $C . d$. terrificus, and $C$. $d$. collilineatus subspecies (Figure 4). Statistical analysis revealed that systemic bleeding was associated with unclottable blood in this group of patients $(\mathrm{OR}=4.77$, CI95\% 1.28-17.70; $\mathrm{P}=0.021)$.

Table 3: Clinical characteristics of $C$. $d$. ruruima envenomings reported in the state of Roraima, northern Brazilian Amazon, from 2010 to 2019.

\begin{tabular}{|c|c|c|}
\hline Variable & Number & $\%$ \\
\hline \multicolumn{3}{|l|}{ Local manifestations } \\
\hline Pain $(n=364)$ & 348 & 95.6 \\
\hline Edema $(n=363)$ & 297 & 81.8 \\
\hline Ecchymosis $(n=358)$ & 21 & 5.9 \\
\hline \multicolumn{3}{|l|}{ Systemic manifestations } \\
\hline Neuroparalysis $(n=376)$ & 83 & 22.1 \\
\hline Myolysis $(n=378)$ & 61 & 16.1 \\
\hline Bleeding $(n=375)$ & 34 & 9.1 \\
\hline Vomiting/diarrhea $(n=374)$ & 31 & 8.3 \\
\hline \multicolumn{3}{|l|}{ Clotting time $(n=113)$} \\
\hline Normal & 50 & 44.2 \\
\hline Prolonged & 63 & 55.8 \\
\hline \multicolumn{3}{|c|}{ Severity grade on admission* $(n=381 ; 96.2 \%)$} \\
\hline Mild & 151 & 39.6 \\
\hline Moderate & 170 & 44.6 \\
\hline Severe & 60 & 15.7 \\
\hline \multicolumn{3}{|c|}{ Antivenom administration $(n=381 ; 96.2 \%)$} \\
\hline Underdosage & 155 & 40.7 \\
\hline As recommended & 226 & 59.3 \\
\hline \multicolumn{3}{|l|}{ Local complications } \\
\hline Secondary infection $(n=345)$ & 11 & 3.2 \\
\hline Necrosis $(n=343)$ & 4 & 1.2 \\
\hline Compartment syndrome $(n=344)$ & 2 & 0.6 \\
\hline Functional loss $(n=343$ ) & 3 & 0.9 \\
\hline Amputation ( $n=343$ ) & 1 & 0.3 \\
\hline \multicolumn{3}{|l|}{ Systemic complications } \\
\hline Acute renal failure $(n=336)$ & 33 & 9.8 \\
\hline Respiratory failure $(n=335)$ & 8 & 2.4 \\
\hline Sepsis $(n=335)$ & 2 & 0.6 \\
\hline Shock $(n=334)$ & 5 & 1.5 \\
\hline \multicolumn{3}{|l|}{ Death $(n=350)$} \\
\hline Yes & 4 & 1.1 \\
\hline
\end{tabular}


Clotting time, usually performed as the Lee-White clotting time (LWCT) or the 20-minute whole-blood clotting test (20WBCT) usually employed to determine the clotting time, are used worldwide as reliable, low- cost techniques to assess snakebite coagulopathy. Prolonged clotting time assesses the consumption/deficiency in coagulations factors, as well as alterations in platelet count and function [140]. The venom is a cocktail of toxins capable of interefering with hemostatic components, leading to coagulopathy. Prolonged clotting times are associated with antagonistic behavior of toxins, which can induce anticoagulant activity, as described for crotoxin and crotamine [79,141], and procoagulant toxins, reported by serine proteases with thrombin-like activity, which induces the consumption of coagulation factor and hypofibrinogenemia $[78,79]$. The overall activity induces blood incoagulability, an important factor in bleeding genesis. Another relevant element in hemorrhagic events consists of platelet depletion and the impaired function, majorly promoted by the platelet aggregation agonist convulxin [85], with the backup of others toxins such as crotoxin and crotamine [97,142] working as agonist and antagonist of platelet aggregation, respectively.

Another interesting aspect concerns the possible role of SVMP from $C$. durissus subspecies venom acting as hemorrhagins. Although their biological activities have not been investigated, SVMP found in North-America in Crotalus venoms have been described as inducing local hemorrhage through vessel basement membrane degradation [93], as also observed in Bothrops species [143]. Considering its abundance in $C$. $d$. ruruima compared to other venoms, this group of toxins could be associated with the high frequency of bleeding events in patients from Roraima state.

\section{Neurological Disorders}

Neurological impairment observed in $C$. durissus envenomings is associated with the action of neurotoxins, which are found to act in both peripheral and central nervous systems [96,144,145]. In the clinical description from the Extra-Amazonian region, neuroparalytic signs, especially the neurotoxic facies/palpebral 
ptosis, are the most frequent signs of Crotalus envenomings. In general, palpebral ptosis is observed in $\sim 70 \%$ of the patients $[118,124]$ and in $\sim 90 \%$ of the children [116,117]. Ophthalmoplegia and diplopia are also very frequent, appearing in $95 \%$ of general patients and $81 \%$ of the children, respectively [117]. In the cases reported in the state of Pará, these neurological manifestations are present in almost all patients $[126,146,147]$. Bucaretchi and colleagues report an envenoming case caused by a juvenile $C$. $d$. terrificus that evolved with coagulopathy as the main systemic manifestation, without neuromyotoxic features normally associated with bites by adult specimens [136]. In $C$. $d$. ruruima envenomings, the frequency of palpebral ptosis ranged from 24.3 [26] to 50\% [115], and diplopia was seen in $21.6 \%$ of the patients [26]. Dizziness, difficulty in walking, and muscle weakness are manifestations less frequent in Crotalus snakebites, including those caused by C. $d$. ruruima $[26,59,115]$. In the patients reported to SINANRoraima, neuroparalytic signs were detected in $22.1 \%$ of the patients (Table 3). Compared to other Crotalus subspecies, neuroparalytic signs were significantly less prevalent in $C$. $d$. ruruima compared to other $C$. durissus subspecies, except when comparing to $C$. d. durissus (Figure 4).

Respiratory failure is also a rare complication from $C$. durissus snakebites, being associated with severe cases of envenomings resulting from paralysis of the rib cage and diaphragm muscles $[148,149]$. A previous report on two cases of $C$. $d$. terrificus snakebite showed that respiratory manifestations emerged within the first 48 hours and were characterized by dyspnea, tachypnea, use of accessory muscles of respiration, and decreased blood $\mathrm{pH}$ and imbalanced $\mathrm{pO}_{2} \quad \mathrm{pCO}_{2}$ levels [148]. SINAN database analysis revealed that the frequency of this complication ranged from $0 \%$ in $C$. $d$. marajoensis to $2.4 \%$ in $C$. $d$. ruruima envenomings. The frequency of respiratory failure was significantly higher in $C . d$. ruruima than in $C$. d. terrificus envenomings $(0.5 \%)$ (Figure 4$)$.

As neurological manifestations and respiratory failure are both associated with the venom neuroxicity, in which crotoxin plays a major role [127], it is possible that the difference in neurotoxic 
activity could be associated with the singular potency of crotoxin found in each venom. Cavalcante and colleagues showed that crotoxin isolated from $C$. $d$. cumanensis (inhabit Colombia, Venezuela, and Caribbean coast) presents a more potent neuromuscular blockade effect on mice phrenic-diaphragm preparations when compared to that of $C$. d. ruruima [68].

\section{Other Manifestations}

Gastrointestinal manifestations, such as nausea (21.6\%), vomiting (8.1 to $12.5 \%$ ), and abdominal pain (8.1\%), are reported in $C$. $d$. ruruima envenomings [26,115]. Necrosis, compartment syndrome, functional loss, and amputation were rare, and their frequencies were similar between envenomings caused by different $C$. durissus subspecies. Headache prevalence ranged from 12.5 [115] to $24.3 \%$ [26]; dizziness in $12.5 \%$ [115]; and fever in $8.1 \%$ of the patients [26].

\section{Risk Factors for Severity}

In Brazil, severity classification of Crotalus envenomings takes into account the neurological and myolytical signs and symptoms, added to the presence of acute renal failure [139] (Table 4). However, bite site manifestations and coagulopathy are not listed as predictors of severity in the Brazilian guideline.

Table 4: Severity classification of Crotalus bites according the Brazilian Ministry of Health.

\begin{tabular}{llll}
\hline Signs/symptoms & & Case severity & \\
\cline { 4 - 4 } & Mild & Moderate & Severe \\
\hline Neuroparalytic manifestations (myasthenic facies and others) & Mild & Evident & Evident \\
Myalgia & Absent & Mild & Mvident \\
Dark urine & Absent & Mild & Evident \\
Oliguria/anuria & Absent & Absent & Evident \\
\hline
\end{tabular}

Source: Brazilian Ministry of Heatth (139).

Table 5 summarizes the results of the univariable and multivariable logistic regression models evaluating factors associated with severity in $C$. $d$. ruruima envenomings reported to SINAN-Roraima from 2010 to 2019. Antivenom underdosage $[\mathrm{RR}=1.91(95 \% \mathrm{CI}=1.18-3.09) ;(\mathrm{p}=0.008)]$, time to medical care $>6$ hours $[\mathrm{RR}=1.85 \quad(95 \% \mathrm{CI}=1.14-2.99) ; \quad(\mathrm{p}=0.013)]$, and 
Amerindian ethnicity [RR=1.84 (95\% $\mathrm{CI}=1.04-3.26) ;(\mathrm{p}=0.036)]$ were independently associated with the risk of severity. Bites in lower limbs $[\mathrm{RR}=0.44(95 \% \mathrm{CI}=0.26-0.76) ;(\mathrm{p}=0.003)]$ were associated with protection from severity.

Table 5: Factors associated with severity in $C$. $d$. ruruima envenomings reported in the state of Roraima, northern Brazilian Amazon, from 2010 to 2019.

\begin{tabular}{|c|c|c|c|c|c|c|}
\hline Severity\# & RR & $95 \% \mathrm{Cl}$ & $P$ & aRR & $95 \% \mathrm{Cl}$ & $P$ \\
\hline Underdosage & 1.69 & $1.06-2.69$ & 0.026 & 1.91 & $1.18-3.09$ & 0.008 \\
\hline Time to care $>6$ hours & 1.79 & $1.11-2.91$ & 0.018 & 1.85 & $1.14-2.99$ & 0.013 \\
\hline Amerindian ethnicity & 1.45 & $0.85-2.48$ & 0.166 & 1.84 & $1.04-3.26$ & 0.036 \\
\hline Site of the bite (lower limbs) & 0.51 & $0.30-0.87$ & 0.014 & 0.44 & $0.26-0.76$ & 0.003 \\
\hline \multicolumn{7}{|l|}{ Schooling (years) } \\
\hline Iiterate & 1 & & & & & \\
\hline$\$ 4$ & 0.81 & $0.30-2.19$ & 0.687 & & & \\
\hline $5-8$ & 1.03 & $0.37-2.87$ & 0.950 & & & \\
\hline$>8$ & 0.94 & $0.34-2.57$ & 0.913 & & & \\
\hline Gender (Women) & 0.67 & $0.35-1.27$ & 0.227 & & & \\
\hline Work-related & 1.35 & $0.69-2.66$ & 0.371 & & & \\
\hline Rural zone & 1.37 & $0.46-4.07$ & 0.568 & & & \\
\hline \multicolumn{7}{|l|}{ Age (years) } \\
\hline$\leq 15$ & 1 & & & & & \\
\hline $16-45$ & 0.97 & $0.55-1.67$ & 0.906 & & & \\
\hline $46-60$ & 1.08 & $0.50-2.33$ & 0.842 & & & \\
\hline$>60$ & 1.09 & $0.44-2.72$ & 0.844 & & & \\
\hline
\end{tabular}

Antivenom underdosage was previously reported as a risk factor for death in the Brazilian Amazon [150], being more frequent in Amerindian patients [114]. Incomplete treatments may be associated to with the lack of trained health professionals assisting snakebites and antivenom shortage, forcing professionals to rationalize the limited stock among patients. As also discussed in previous reports $[150,151]$, late medical care was found to be a risk factor of severity. In these cases, venom toxins acting longer in the body increase the possibility of systemic complications due to more intense myolysis $[59,117]$. Amerindian ethnicity was also independently associated with the risk of severity, it is necessary to consider the main challenges with cultural, social, and economic disparities between Amerindians and non-Amerindians to understand this association. Firstly, Amerindian villages have their own and very verticalized health system, presenting a low performance in treating snakebites resulting in a higher frequency of long-term disabilities and deaths in these groups [114]. Moreover, traditional therapeutic practices within the community involving healers such as shamans, those with knowledge of medicinal plants, and animal-based medicines are often provided in the 
villages [152]. This has a consequence in the time to medical assistance, and the use of deleterious procedures is not discarded [114]. Bites in lower limbs were independently associated with milder envenomings. We do not understand the mechanism of this finding, but it may be related to a different bioavailability profile of the venom in the patient's body according to the bite site. In other studies, older age was associated with severity in rattlesnake envenomings $[113,153]$. This association was not found in $C$. $d$. ruruima envenomings reported to SINANRoraima, possibly because the number of cases in patients $\geq 61$ years was very small. Indeed, statistical analysis revealed that cases in the state of Roraima occurred mostly in the younger population, as compared to other regions of Brazil $(\mathrm{P}<0.0001)$.

\section{Therapeutics against $C$. d. Ruruima Envenomings Specific Treatment}

Specific antivenom is crucial for the efficiency of the treatment of rattlesnake envenomings [154]. For the treatment of Crotalus envenomings in areas where $C . d$. ruruima occurs, there are three types of antivenoms, two produced in Brazil and one in Venezuela. Characteristics of these products are described in Table 6. Although the Brazilian antivenoms are produced using only one or two rattlesnake subspecies venoms $(C$. $d$. terrificus $100 \%$ or $C$. $d$. terrificus $50 \%$ plus $C$. $d$. collilineatus $50 \%$ ), both have been used to treat envenomings caused by all the six Crotalus subspecies in Brazil $(C . d$. durissus, $C$. d. terrificus, $C$. $d$. cascavella, $C$. d. ruruima, $C$. d. marajoensis, and $C$. $d$. collilineatus) $[26,149,155]$. The three producers of crotalid antivenoms in the country follow the guidelines of the Agência Nacional de Vigilância Sanitária (Brazilian National Health Surveillance Agency, ANVISA). While each producer uses its own crotalid venoms, all of them use crotamine-abundant venoms in their antigen mixtures [156] (for details, see Section 2 ). The antivenoms are distributed by the government free of charge. The dosage can vary according to the envenoming severity, though there are standardized recommendations of dosage according to the severity of the case [157]. Likewise, Venezuelan antivenom is produced using $C$. $d$. cumanensis venom, and it is used to treat Crotalus envenomings caused by 
different subspecies occurring in Venezuela [158]. Although with adequate, specific and general treatment, most victims envenomed by rattlesnakes can recover and survive, there is some evidence suggesting that the Crotalus antivenom cannot neutralize all the deleterious actions of the venom [49]. Although crotalid antivenom was effective in neutralizing the lethal, myotoxic, and in vitro coagulant activities of the venoms of $C . d$. terrificus, $C$. simus, and $C$. d. cumanensis [159], as well as the lethal effect of $C$. d. ruruima [49] and $C$. basiliscus venoms [160], this antivenom was ineffective in the neutralization of hemorrhagic activity of $C . d$. ruruima venom [49,159]. Hemorrhage was inhibited in the experimental $C$. $d$. ruruima envenoming only by using the Bothrops-Crotalus antivenom, possibly due to the sharing of hemorrhagic toxins with Bothrops species [49]. Follow-up of four patients envenomed by $C$. $d$. ruruima has shown that neurotoxic signs ceased, and hemostasis parameters and CK values returned to normal 24 hours after treatment with the Bothrops-Crotalus antivenom [115]. Otherwise, preliminary reports from the Snakebite Roraima group (Boa Vista, RR, Brazil- www.snakebiteroraima.com) have documented that, in some $C$. $d$. ruruima envenoming cases, the antivenom does not seem to reverse the venom-induced signs [59]. Indeed, antivenomic studies or detailed in vivo neutralizing assays with this subspecies venom to elucidate the antivenom efficacy are lacking. Venomics results (see Table 1) suggest that different subspecies venoms induce a different proportion of specific antibodies when inoculated in horses; thus, the antivenom manufactured for $C . d$. terrificus and $C . d$. colillineatus venoms may not contain neutralizing antibodies for all $C . d$. ruruima toxins.

Table 6: Crotalus antivenoms available in areas where Crotalus durissus ruruima area reported, in Brazil and Venezuela.

\begin{tabular}{|c|c|c|c|c|}
\hline Laboratory (Country) & Antivenom & Description of the antivenom & Venoms used for production & Dosage \\
\hline $\begin{array}{l}\text { Butantan Institute (IBU), } \\
\text { Vital Brazil Institute (INB), } \\
\text { and Ezequiel Dias } \\
\text { Foundation (FUNED) } \\
\text { (Brazil) }\end{array}$ & $\begin{array}{l}\text { Crotalus } \\
\text { AV }\end{array}$ & $\begin{array}{l}\text { Each vial contains heterologous horse F(ab')2, } \\
\text { neutralizing at } 15 \mathrm{mg} \text { of the reference venom of } C . d \text {. } \\
\text { terrificus, in mice, phenol ( } 35 \mathrm{mg} \text { maximum) and } \\
\text { physiological solution } 0.85 \% \text { q.s. } 10 \mathrm{~mL} \text {. }\end{array}$ & $\begin{array}{l}\text { C. d. terrificus } 50.0 \% \text { plus C. d. collinineatus } 50.0 \% \\
\text { (IBU) or C. d. terrificus } 100 \% \text { (INB and FUNED) }\end{array}$ & $\begin{array}{l}5 \text { vials to mild } \\
\text { cases, } 10 \text { vials } \\
\text { to moderate } \\
\text { cases, } 20 \text { vials } \\
\text { to severe cases }\end{array}$ \\
\hline $\begin{array}{l}\text { Butantan Institute (IBU), } \\
\text { Vital Brazil Institute (IVB), } \\
\text { and Ezequiel Dias } \\
\text { Foundation (FUNED) } \\
\text { (Brazil) }\end{array}$ & $\begin{array}{l}\text { Bothrops- } \\
\text { Crotalus } \\
\text { AV }\end{array}$ & $\begin{array}{l}\text { Each vial contains heterologous horse } F(a b \text { ') } 2 \text {, } \\
\text { neutralizing at least } 50 \mathrm{mg} \text { and } 15 \mathrm{mg} \text { of the reference } \\
\text { venoms of Bothrops jararaca and C. d. terrificus, } \\
\text { respectively, in mice, phenol ( } 35 \mathrm{mg} \text { maximum) and } \\
\text { physiological solution } 0.85 \% \text { qs. } 10 \mathrm{~mL} \text {. }\end{array}$ & $\begin{array}{l}\text { Bothrops genus (B. jararaca } 50.0 \% \text {, B. alternatus } \\
12.5 \%, B \text {. jararacuçu } 12.5 \%, B \text {. moojeni } 12.5 \% \\
\text { and B. neuweidi } 12.5 \%) \text {, Crotalus genus (C. d. } \\
\text { terrificus } 50.0 \% \text { plus C. d. collitineatus } 50.0 \% \text { - IBU, } \\
\text { or C. d. ternificus } 100 \% \text { - NB and FUNED) }\end{array}$ & $\begin{array}{l}5 \text { vials to mild } \\
\text { cases, } 10 \text { vials } \\
\text { to moderate } \\
\text { cases, } 20 \text { vials } \\
\text { to severe cases }\end{array}$ \\
\hline $\begin{array}{l}\text { BIOTECFAR - } \\
\text { Biotechnology Center, } \\
\text { Venezuela Faculty of } \\
\text { Pharmacy of the } \\
\text { Venezuela University } \\
\text { Center (Nenezuela) }\end{array}$ & $\begin{array}{l}\text { Bothrops- } \\
\text { Crotalus } \\
\text { AV }\end{array}$ & $\begin{array}{l}\text { Each vial contains heterologous horse } F(a b ') 2 \text {, } \\
\text { neutralizing at least } 20 \mathrm{mg} \text { of the reference venom of } \\
\text { Bothrops colombiensis and } 15 \mathrm{mg} \text { of the reference } \\
\text { venom of } C \text {. cumanensis, in mice, phenol ( } 30 \mathrm{mg} \\
\text { maximum) and physiological solution } 0.85 \% \text { q.s. } 10 \mathrm{~mL}\end{array}$ & Bothrops colombiensis and $C$. d. cumanensis & $\begin{array}{l}10 \text { vials to } \\
\text { moderate } \\
\text { cases and } 15 \\
\text { vials to severe } \\
\text { cases }\end{array}$ \\
\hline
\end{tabular}


The need for a cold chain and physicians to prescribe antivenoms usually restricts access to effective snakebite treatment [161]. However, as presented above, $C . d$. ruruima envenomings are reported mostly in Amerindian populations, and it is necessary to consider challenges related to cultural, social, and economic disparities between Western and indigenous cultures, contributing to late medical care among the latter [114]. In Roraima, some Yanomami sanitary districts have antivenom available for mild to moderate snakebite cases [162], but in the other indigenous groups, referral to urban areas is needed. The transfer of the indigenous to urban areas is a critical event in these individuals lives, due to the breakdown of relations with the village and eating habits, causing treatment refusals [114]. From an economic point of view, the public health system spends thousands of dollars per year to transport indigenous patients by plane or helicopter ( US\$600 and US $\$ 900 /$ hour of flight, respectively), in addition to hospital costs and loss of productivity, which are also very high (US\$8 million in 2015, in the Amazon region) [163]. Besides the specific treatment, supportive assistance during severe rattlesnake treatment is crucial but possible only in the capital, Boa Vista. Strategies that guarantee this affected population's cases timely access to treatment and proper training of health professionals who deal with indigenous populations are key to providing the best care to the indigenous communities. In a previous study, we discuss a plan for the decentralization of antivenom treatment to local healthcare facilities as an intervention to increase the indigenous population's access to proper healthcare [114].

An important fact to be mentioned is the absence of antivenoms in the health facilities of neighboring countries where $C . d$. ruruima envenomings are also common. In Guyana, for example, health authorities have only recently announced the acquisition of antivenoms (the polyvalent antivenom PoliValICP, Instituto Clodomiro Picado, Costa Rica), which are available only in Georgetown, the country's capital [164]. The country has one of the highest case fatality rates $(\sim 8 \%)$ on the continent, which is explained by the fact that few patients visit the health facilities offering proper treatment [165]. Envenomings by $C$. $d$. ruruima are reported in the Guianan 
savanna, especially in the Lethem region, on the border with Brazil [59]. In the absence of antivenoms in these localities, and because of the nearly nonexistent evacuation possibilities to the capital, these patients seek treatment in Brazil. In Venezuela's case, the Laboratorios BIOTECFAR, a public producer maintained by Universidad Central de Venezuela, responsible for the production of antivenoms in the country, has experienced difficulty maintaining continuous production in the last years [158]. The shortage of antivenom in Venezuelan is suggested as the cause of patients seeking treatment in Brazil after severe snakebites [166].

\section{Heterologous Antivenom Disadvantages and Next- Generation Crotalid Antivenoms}

Although promising results suggest that the $\mathrm{PLA}_{2}$ inhibitors varespladib and methyl-varespladib are effective in preventing neurotoxic manifestations induced by $C$. d. terrificus [167], crotalid heterologous antivenoms are the only available effective treatment for rattlesnake envenomings in endemic areas. As other heterologous antivenoms, they may present undesirable problems, such as anaphylactic reactions, and serum sickness. Moreover, many of the antibodies from antivenoms ( 70\%) are composed of non-neutralizing antibodies [for review, see [168]]. Thus, it is evident that the century-old crotalid therapy introduced by Vital Brazil in 1901 [169] needs to be improved. The information on the safety of Crotalus antivenoms is scarce, but it was estimated that $80 \%$ of patients developed developed an early, adverse event of early adverse event after using the available Brazilian Crotalus antivenom, with no significant difference in the frequency of patients with early reactions between the groups that were and were not pretreated with antihistamines and corticosteroids [116]. Even though the antivenom purification process has, over time, contributed to reducing this frequency to around $20 \%$ today [115], the possibility of early reactions generates fear among health professionals and is a major obstacle for antivenom decentralization to remote areas [114]. 
The first approach to decreasing the size of the immunocomplexes generated by heterologous antivenoms and preventing side effects (e.g., serum sickness) treated all immunoglobulins (IgGs) with specific enzymes. This methodology results in antigen-binding fragments $\mathrm{F}\left(\mathrm{ab}{ }^{\prime}\right)_{2} \mathrm{~s}$ or Fabs [170], which are much smaller, corresponding to 115 and $50 \mathrm{kDa}$, respectively (a whole IgG presents $\sim 150 \mathrm{kDa}$ ) [171]. At the moment, most of the animal-derived crotalid antivenoms are composed of antibody fragments (e.g., CroFab [172], BIOTECFAR from Venezuela, and both crotalid antivenoms from Brazilian producers). Although the antibody size reduction was important for improving antivenom therapy [173], the molecules continue to cause side effects in keeping their heterologous nature. Indeed, the Instituto Clodomiro Picado from Costa Rica still produces crotalid antivenoms composed of whole IgGs [174].

Animal plasma-derived antivenoms will continue to be the cornerstone of envenoming therapy for many years to come, and it may indeed be warranted to further improve these life-saving medicines e.g. via improved downstream processing or improved immunization approaches [175]. However, further into the future, it is not unlikely that recombinant DNA technology and the application of human monoclonal antibodies and/or nanobodies may find their way into the field [176]. Indeed, the development of monoclonal antibodies to treat envenomings caused by venomous animals is now being extensively investigated [177-181], although none have so far been tested in human patients. Here, we will explore only the discoveries regarding experimental crotalid antivenoms.

Antibody phage display [182] has been used as the main successful technology to generate monoclonal antibodies against toxins. In 1995, the technique was first used for the discovery of monoclonal antibody fragments against animal toxins [176]. Interestingly, the target toxin was a crotoxin obtained from the snake $C$. $d$. terrificus [183]. Although the mouse-derived library construction and the antibody panning were performed appropriately, the selected antibody failed to inhibit the $\mathrm{PLA}_{2}$ activity induced by crotoxin. In 1997, the first human 
monoclonal antibody generated by phage display against crotoxin was obtained. The research group discovered scFvs targeting crotoxin from a human semi-synthetic antibody phage display library, and the antibodies demonstrated to bind the toxin in ELISA assays [184].

In 2009, a non-immune human single-chain fragment variable library (Griffin.1) was used to select antibodies against $C$. $d$. terrificus $\mathrm{PLA}_{2} \mathrm{~s}$. Two clones demonstrated the ability to partially inhibit the PLA $\mathrm{P}_{2}$ activity in vitro, to reduce the myotoxic and edema activities of basic crotoxin in vivo, and to inhibit the lethality of $C . d$. terrificus venom in an experimental envenoming [185]. Later (2018), using previous phage display selections, the same research group discovered scFv clones able to cross-inhibit in vitro indirect hemolysis and plasma-clotting effects of $C$. $d$. terrificus and Bothrops jararacussu venoms [186]. Using a phage display peptide library, Titus and colleagues (2017) also developed peptides against a PLA 2 consensus peptide from North American rattlesnakes, $C$. adamanteus, C. atrox, C. scutulatus, Agkistrodon piscivorus, and A. contortrix laticinctus. $\mathrm{PLA}_{2} \mathrm{~s}$ from these venoms had their in vitro enzyme activity slightly reduced by the selected peptides by $40 \%$ or less [187].

Thus far, the discovery of monoclonal antibodies and peptides have only yielded inhibitors of crotoxin and $\mathrm{PLA}_{2} \mathrm{~S}$ from Crotalus spp, with no reports on monoclonal antibodies against crotamine or other rattlesnake venom compound. Part of the explanation for this may be that $\mathrm{PLA}_{2} \mathrm{~S}$ seem to dominate as antigens compared to other venom components. Campos et al. demonstrated that when snake whole venoms were used as targets in phage display panning rounds, antibodies were primarily selected against $\mathrm{PLA}_{2}$ proteins [180]. To overcome this difficulty, key toxins that are important to neutralize, but which are not dominant in neither phage display campaigns or immunization schemes, can be carefully isolated or recombinantly expressed to provide more control over the antibody selection or immunization process [188-190]. In the future, such efforts could hypothetically both be used to identify antibodies that could be used to fortify existing crotalid 
antivenoms [191], and thereby extend their species coverage, or improve their efficacy against non-immunogenic components [190]. Finally, it is speculated that efforts focusing on the discovery and development of monoclonal antibodies against Crotalus toxins could possibly enable the design of fully recombinant antivenoms based on oligoclonal mixtures of antibodies targeting all medically important venom toxins [192]. If such efforts became fruitful, they could lead to better envenoming therapies with improved safety and efficacy, allowing for the deployment of such products in remote areas due to a decreased risk of anaphylactic shock and other serious immunological reactions [193]. Such potential improvements could have a profound impact on rural communities in regions such as the Amazon, however, it is important to stress that all research efforts reported so far are in very early development. If monoclonal antibodies will one day find their way into clinical development, this will likely be several years into the future. Meanwhile, plasma-derived antivenoms will remain the mainstay of envenoming therapy against Crotalus spp.

\section{Concluding Remarks}

C. $d$. ruruima bites represent an important public health issue in the northernmost state of Brazil, Roraima, given the predominance of this snake subspecies in the region and the severity of its bite. Envenoming pathophysiology includes pain, edema, myolysis, bleeding, uncoagulable blood, renal dysfunction, and respiratory impairment, which have been observed more frequently in patients envenomed by $C$. $d$. ruruima compared to other $C$. durissus subspecies. We identified that antivenom underdosage, time to medical care, and being part of an indigenous population are risk factors of rattlesnake envenoming in Roraima state. Therefore, $C$. $d$. ruruima snakebites deserve special attention in the clinical and therapeutic management by health professionals. Also, better strategies for accessing specific antivenom through public distribution policies are needed. It is evident that $C$. $d$. ruruima venom is still among the least explored venoms from Crotalus species, with little existing data on its toxins and induced effects. 
Prime Archives in Immunology: $2^{\text {nd }}$ Edition

\section{References}

1. Wüster W, Ferguson JE, Quijada-Mascareñas JA, Pook CE, Graça Salomão M, et al. Tracing an Invasion: Landbridges, Refugia, and the Phylogeography of the Neotropical Rattlesnake Serpentes: Viperidae: Crotalus durissus: Phylogeography of the Neotropical Rattlesnake. Mol Ecol. 2005; 14: 1095-1108.

2. Costa HC, Bérnils RS. Répteis do Brasil e suas Unidades Federativas: Lista de Espécies. Herpetol Bras. 2018; 7: 1157.

3. Hoge AR. Preliminary Account on Neotropical Crotalinae Serpentes, [Viperidae]. Memórias do Inst Butantan. 1966; 32: $109-184$.

4. Hoge AR, Romano SA. Sinopse das Serpentes Peçonhentas do Brasil. [Serpentes, Elapidae E Viperidae]. Memórias do Inst Butantan. 1972; 36: 109-208.

5. Calvete JJ, Sanz L, Cid P, de la Torre P, Flores-Díaz M, .et al. Snake Venomics of the Central American Rattlesnake Crotalus simus and the South American Crotalus durissus Complex Points to Neurotoxicity as an Adaptive Paedomorphic Trend Along Crotalus Dispersal in South America. J Proteome Res. 2010; 9: 528-544.

6. de Carvalho AEZ, Giannotti K, Junior EL, Matsubara M, Santos MCD, et al. Crotalus durissus ruruima Snake Venom and a Phospholipase $\mathrm{A}_{2}$ Isolated from this Venom Elicit Macrophages to Form Lipid Droplets and Synthesize Inflammatory Lipid Mediators. J Immunol Res. 2019; 2019: 2745286.

7. Campbell JA, Lamar WW. The Venomous Reptiles of Latin America 2004. Ithaca: Cornell Univ. Press. Available online at: https://www.journals.uchicago.edu/doi/10.1086/417006

8. Vanzolini PE, Calleffo MEV. A Taxonomic Bibliography of the South American Snakes of the Crotalus durissus Complex Serpentes, [Viperidae]. Acad Bras Ciênc. 2002; 74: 37-83.

9. Bastos EGM, Araújo AFB, Silva HR. Records of the Rattlesnakes Crotalus durissus terrificus [Laurenti] [Serpentes, Viperidae] in the State of Rio de Janeiro, Brazil: 
Prime Archives in Immunology: $2^{\text {nd }}$ Edition

A Possible Case of Invasion Facilitated by Deforestation. Rev Bras Zool. 2005; 22: 812-815.

10. Peters JA, Orejas-Miranda B. Catalogue of the Neotropical Squamata. Part I. Snakes. Bulletin. 1970; 297: 1-347.

11. Cunha OR, Nascimento FP. Ofídios Da Amazônia. Xi. Ofídios de Roraima e Notas sobre Erythrolamprus bauperthuisii Duméril, Bibron \& Duméril, 1954, Sinônimo de Erythrolamprus aesculapii [Linnaeus, 1758]. In: Boletim do Museu Paraense Emílio Goeldi, Nova Série Zoologia. $1980 ; 1-21$.

12. Harris HS Jr., Simmons RS. A New Subspecies of Crotalus durissus Serpentes: (Crotalidae) from the Rupununi Savanna of Southwestern Guyana. Memórias do Inst Butantan. 1978; 40: 305-311.

13. Abuys A. The Snakes of Surinam, Part XIX: Family Viperidae, Subfamily Crotalinae [Genus Crotalus] Vol. 31. Jukwerderweg, Appingedam, The Netherlands: litt Serp. 1987; 282-296.

14. Rubio M. Rattlesnake: Portrait of a Predator. Washington: Library of Congress Cataloging in Publication Data Rubio, Manny. 1988.

15. Rocha AM. Dieta e Comportamento Alimentar de Crotalus durissus ruruima Hoge, 1965 [Viperidae], em uma Área de Lavrado em Roraima. Brasil: Faculdade Cathedral. 2017.

16. Madsen T, Shine R. Costs of Reproduction in a Population of European Adders. Oecologia. 1993; 94: 488-495.

17. Almeida-Santos SM, Laporta-Ferreira IL, Puorto G. Ritual de Combate em Crotalus durissus. Anais da Acad Bras Ciências. 1990; 62: 418.

18. de Langlada FG. Combat-Dance between Males of Brazilian Crotalus durissus. J Herpetol. 1975; 9: 349.

19. O'Shea M, Milliken W, Ratter JA. The Reptilian Herpetofauna of the Ilha De Maracá Cap. 12. Maracá: The Biodiversity and Environment of an Amazonian Rainforest. Chichester: John Wiley \& Sons. 1998; 231-262.

20. Tozetti AM, Martins M. Habitat Use by the South American Rattlesnake Crotalus durissus; in South Eastern Brazil. J Natural History. 2008; 42: 1435-1444.

21. Sawaya RJ, Marques OAV, Martins M. Composition and Natural History of a Cerrado Snake Assemblage at Itirapina, 
Prime Archives in Immunology: $2^{\text {nd }}$ Edition

São Paulo State, Southeastern Brazil. Biota Neotrop. 2008; 8.

22. Farias RES. Taxocenose de Serpentes em Ambientes Aquáticos de Áreas de Altitude em Roraima Squamata: (Serpentes). 2016. Available online at: https://bdtd.inpa.gov.br/handle/tede/2135.

23. Tozetti AM, Vettorazzo V, Martins M. Short-Term Movements of the South American Rattlesnake Crotalus durissus; in Southeastern Brazil. Herpetol J. 2009; 22: 201206.

24. Sazima I. Um Estudo de Biologia Comportamental da Jararaca, Bothrops jararaca, com Uso de Marcas Naturais. Memórias do Inst Butantan. 1988; 50: 83-99.

25. Nascimento SP. Aspectos Epidemiológicos dos Acidentes Ofídicos Ocorridos no Estado de Roraima, Brasil, entre 1992 e 1998. Cad Saúde Pública. 2000; 16: 271-276.

26. Asato MS, Cruz Carbonell RC, Martins AG, Mendonça de Moraes C, Chávez-Olórtegui $\mathrm{C}$, et al. Envenoming by the Rattlesnake Crotalus durissus ruruima in the State of Roraima, Brazil. Toxicon X. 2020; 8: 100061.

27. Sant'Anna SS, Abe AS. Diet of the Rattlesnake Crotalus durissus in Southeastern Brazil Serpentes, (Viperidae). Stud Neotrop Fauna Environ. 2007; 42: 169-74.

28. Salomão MG, Santos SMA, Puorto G. Activity Pattern of Crotalus durissus Viperidae, (Crotalinae): Feeding, Reproduction and Snakebite. Stud Neotrop Fauna Environ. 1995; 30: 101-106.

29. Hoyos MA, Almeida-Santos SM. The South-American Rattlesnake Crotalus durissus: Feeding Ecology in the Central Region of Brazil. Biota Neotrop. 2016; 16: e20140027.

30. Vanzolini PE, Costa AMMR, Vitt LJ. Repteis das Caatingas. Rio de Janeiro: Academia Brasileira de Ciencias. 1980.

31. Rocha A, Viana P. Leptodactylus Macrosternum, A Fatal Prey for a Juvenile Crotalus durissus. Herpetozoa. 2019; 31: 219-220.

32. Barros VA, Sueiro LR, Almeida-Santos SM. Reproductive Biology of the Neotropical Rattlesnake Crotalus durissus from Northeastern Brazil: A Test of Phylogenetic 
Prime Archives in Immunology: $2^{\text {nd }}$ Edition

Conservatism of Reproductive Patterns. Herpetol J. 2012; 22: 97.

33. Almeida-Santos SM, Orsi AM. Ciclo Reprodutivo de Crotalus durissus e Bothrops jararaca Serpentes, (Viperidae): Morfologia e Função do Oviduto. Rev Bras Reprodução Anim. 2002; 26: 109-112.

34. Almeida-Santos SM, Salomão MG. Long Term Sperm Storage in the Female Neotropical Rattlesnake Crotalus durissus terrificus Viperidae: (Crotalidae). Japanese J Herpetol. 1997; 17: 46-52.

35. Araújo WF, de Andrade Júnior AS, de Medeiros RD, Sampaio RA. Precipitação Pluviométrica Mensal Provável em Boa Vista, Estado de Roraima, Brasil. Rev Bras Engenharia Agrícola e Ambiental. 2001; 5: 563-567.

36. Pyron R, Burbrink FT, Wiens JJ. A Phylogeny and Revised Classification of Squamata, Including 4161 Species of Lizards and Snakes. BMC Evol Biol. 2013; 13: 93.

37. Alencar LRV, Quental TB, Grazziotin FG, Alfaro ML, Martins M, et al. Diversification in Vipers: Phylogenetic Relationships, Time of Divergence and Shifts in Speciation Rates. Mol Phylogenet Evol. 2016; 105: 50-62.

38. Blair C, Sánchez-Ramírez S. Diversity-Dependent Cladogenesis Throughout Western Mexico: Evolutionary Biogeography of Rattlesnakes Viperidae: Crotalinae: Crotalus and Sistrurus;. Mol Phylogenet Evol. 2016; 97: 145-154.

39. Figueroa A, McKelvy AD, Grismer LL, Bell CD, Lailvaux SP. A Species-Level Phylogeny of Extant Snakes with Description of a New Colubrid Subfamily and Genus. PloS One. 2016; 11: e0161070.

40. Carbajal-Márquez RA, Cedeño-Vázquez JR, Martínez-Arce A, Neri-Castro E, Machkour- M'Rabet SC. Accessing Cryptic Diversity in Neotropical Rattlesnakes Serpentes: Viperidae: Crotalus; with the Description of Two New Species. Zootaxa. 2020; 4729: 451-481.

41. Viana PF, Ezaz T, de Bello Cioffi M, Liehr T, Al-Rikabi A, et al. Landscape of Snake' Sex Chromosomes Evolution Spanning 85 MYR Reveals Ancestry of Sequences Despite Distinct Evolutionary Trajectories. Sci Rep. 2020; 10:12499. 
Prime Archives in Immunology: $2^{\text {nd }}$ Edition

42. Lomonte B, Calvete JJ. Strategies in 'Snake Venomics' Aiming at an Integrative View of Compositional, Functional, and Immunological Characteristics of Venoms. J Venom Anim Toxins Incl Trop Dis. 2017; 23: 26.

43. da Silva-Júnior LN, Abreu L de S, Rodrigues CFB, Galizio $\mathrm{N}$ da $\mathrm{C}$, Aguiar $\mathrm{W}$ da $\mathrm{S}$, et al. Geographic Variation of Individual Venom Profile of Crotalus durissus Snakes. J Venom Anim Toxins Incl Trop Dis. 2020; 26: e20200016.

44. Boldrini-França J, Corrêa-Netto C, Silva MMS, Rodrigues RS, De La Torre P, et al. Snake Venomics and Antivenomics of Crotalus durissus Subspecies from Brazil: Assessment of Geographic Variation and Its Implication on Snakebite Management. J Proteomics. 2010; 73: 1758-1776.

45. Tasima LJ, Hatakeyama DM, Serino-Silva C, Rodrigues CFB, de Lima EOV, et al. Comparative Proteomic Profiling and Functional Characterization of Venom Pooled from Captive Crotalus durissus terrificus Specimens and the Brazilian Crotalic Reference Venom. Toxicon. 2020; 185: 26-35.

46. Wiezel GA, Shibao PYT, Cologna CT, Morandi Filho R, Ueira-Vieira $\mathrm{C}$, et al. In-Depth Venome of the Brazilian Rattlesnake Crotalus durissus terrificus: An Integrative Approach Combining its Venom Gland Transcriptome and Venom Proteome. J Proteome Res. 2018; 17: 3941-3958.

47. Georgieva D, Ohler M, Seifert J, von Bergen M, Arni RK, et al. Snake Venomic of Crotalus Durissus TerrificusCorrelation with Pharmacological Activities. J Proteome Res. 2010; 9: 2302-2316.

48. Melani RD, Araujo GDT, Carvalho PC, Goto L, Nogueira FCS, et al. Seeing Beyond the Tip of the Iceberg: A Deep Analysis of the Venome of the Brazilian Rattlesnake, Crotalus durissus terrificus. EuPA Open Proteomics. 2015; 8: 144-156.

49. Dos Santos MC, Ferreira LCL, Da Silva WD, Furtado MFD. Caracterizacion de las Actividades Biologicas de los Venenos 'Amarillo' y 'Blanco' de Crotalus Durissus Ruruima Comparados Con El Veneno De Crotalus durissus terrificus. Poder Neutralizante de los Antivenenos frente a los Venenos de Crotalus durissus ruruima. Toxicon. 1993; 31: 1459-1469. 
Prime Archives in Immunology: $2^{\text {nd }}$ Edition

50. Lourenço A, Zorzella Creste CF, de Barros LC, Delazari dos Santos L, Pimenta DC, et al. Individual Venom Profiling of Crotalus durissus terrificus Specimens From a Geographically Limited Region: Crotamine Assessment and Captivity Evaluation on the Biological Activities. Toxicon. 2013; 69: 75-81.

51. Johnson EK, Kardong KV, Ownby CL. Observations on White and Yellow Venoms from an Individual Southern Pacific Rattlesnake Crotalus viridis helleri. Toxicon. 1987; 25: 1169-1180.

52. Izidoro LFM, Sobrinho JC, Mendes MM, Costa TR, Grabner AN, et al. Snake Venom L-amino Acid Oxidases: Trends in Pharmacology and Biochemistry. BioMed Res Int. 2014; 2014: 196754.

53. Oliveira IS, Cardoso IA, Bordon KCF, Carone SEI, Boldrini-França J, et al. Global Proteomic and Functional Analysis of Crotalus durissus collilineatus Individual Venom Variation and its Impact on Envenoming. J Proteomics. 2019; 191: 153-165.

54. Bon C, Bouchier C, Choumet V, Faure G, Jiang MS, et al. Crotoxin, Half-Century of Investigations on a Phospholipase $\mathrm{A}_{2}$ Neurotoxin. Acta Physiol Pharmacol Latinoam. 1989; 39: 439-448.

55. Hendon RA, Fraenkel-Conrat H. Biological Roles of the Two Components of Crotoxin. Proc Natl Acad Sci USA. 1971; 68: 1560-1563.

56. Choumet V, Bouchier C, Délot E, Faure G, Saliou B, et al. Structure and Function Relationship of Crotoxin, a Heterodimeric Neurotoxic Phospholipase $\mathrm{A}_{2}$ from the Venom of a South-American Rattlesnake. Adv Exp Med Biol. 1996; 391: 197-202.

57. Durban J, Sanz L, Trevisan-Silva D, Neri-Castro E, Alagón $A$, et al. Integrated Venomics and Venom Gland Transcriptome Analysis of Juvenile and Adult Mexican Rattlesnakes Crotalus simus, C. tzabcan, and C. culminatus Revealed Mirna-Modulated Ontogenetic Shifts. J Proteome Res. 2017; 16: 3370-3390.

58. Tokarnia CH, Brito MF, Barbosa JD, Döbereiner J. Quadros Clínico-Patológicos do Envenenamento Ofídico Por Crotalus 
Prime Archives in Immunology: $2^{\text {nd }}$ Edition

durissus terrificus e Bothrops spp. em Animais de Produção. Pesquisa Veterinária Bras. 2014; 34: 301-312.

59. Medeiros JM, Oliveira IS, Ferreira IG, Alexandre-Silva GM, Cerni FA, et al. Fatal Rattlesnake Envenomation in Northernmost Brazilian Amazon: A Case Report and Literature Overview. Reports. 2020; 3: 9.

60. SE. Acidentes por Animais Peçonhentos: Serpentes Peçonhentas. Med Ribeirao Preto (Online). 2003; 36:480.

61. Samy RP, Pachiappan A, Gopalakrishnakone P, Thwin MM, Hian YE, et al. In Vitro Antimicrobial Activity of Natural Toxins and Animal Venoms Tested against Burkholderia pseudomallei. BMC Infect Dis. 2006; 6: 100.

62. Wang J, Qin X, Zhang Z, Chen M, Wang Y, et al. Crotoxin Suppresses the Tumorigenic Properties and Enhances the Antitumor Activity of Iressa ${ }^{\circledR}$ Gefinitib; in Human Lung Adenocarcinoma SPCA-1 Cells. Mol Med Rep. 2014; 10: 3009-3014.

63. Sartim MA, Menaldo DL, Sampaio SV. Immunotherapeutic Potential of Crotoxin: Anti-Inflammatory and Immunosuppressive Properties. J Venom Anim Toxins Incl Trop Dis. 2018; 24: 39.

64. Kini RM. Excitement Ahead: Structure, Function and Mechanism of Snake Venom Phospholipase $\mathrm{A}_{2}$ Enzymes. Toxicon. 2003; 42: 827-840.

65. Six DA, Dennis EA. The Expanding Superfamily of Phospholipase A2; Enzymes: Classification and Characterization. Biochim Biophys Acta. 2000; 1488: 1-19.

66. Ponce-Soto LA, Baldasso PA, Romero-Vargas FF, Winck FV, Novello JC, et al. Biochemical, Pharmacological and Structural Characterization of Two $\mathrm{Pla}_{2}$ Isoforms Cdr-12 and Cdr-13 From Crotalus durissus ruruima Snake Venom. Protein J. 2007; 26: 39-49.

67. Diz Filho EBS, Marangoni S, Toyama DO, Fagundes FHR, Oliveira SCB, et al. Enzymatic and Structural Characterization of New $\mathrm{PLA}_{2}$ Isoform Isolated from White Venom of Crotalus durissus ruruima. Toxicon. 2009; 53: 104-114.

68. Cavalcante WLG, Ponce-Soto LA, Marangoni S, Gallacci M. Neuromuscular Effects of Venoms and Crotoxin-Like 
Prime Archives in Immunology: $2^{\text {nd }}$ Edition

Proteins From Crotalus durissus ruruima and Crotalus durissus cumanensis. Toxicon. 2015; 96: 46-49.

69. Pucca MB, Ahmadi S, Cerni FA, Ledsgaard L, Sørensen $\mathrm{CV}$, et al. Unity Makes Strength: Exploring Intraspecies and Interspecies Toxin Synergism Between Phospholipases $\mathrm{A}_{2}$ and Cytotoxins. Front Pharmacol. 2020; 11: 611.

70. Boldrini-França J, Pinheiro-Junior EL, Peigneur S, Pucca MB, Cerni FA, et al. Beyond Hemostasis: A Snake Venom Serine Protease with Potassium Channel Blocking and Potential Antitumor Activities. Sci Rep. 2020; 10: 4476.

71. de Oliveira DGL, Murakami MT, Cintra ACO, Franco JJ, Sampaio SV, et al. Functional and Structural Analysis of Two Fibrinogen-Activating Enzymes Isolated From the Venoms of Crotalus durissus terrificus and Crotalus durissus collilineatus. Acta Biochim Biophys Sin Shanghai. 2009; 41: 21-29.

72. Braud S, Bon C, Wisner A. Snake Venom Proteins Acting on Hemostasis. Biochimie. 2000; 82: 851-859.

73. Kini RM. Serine Proteases Affecting Blood Coagulation and Fibrinolysis from Snake Venoms. Pathophysiol Haemost Thromb. 2005; 34: 200-204.

74. Kini RM. Toxins in Thrombosis and Haemostasis: Potential beyond Imagination. J Thromb Haemost. 2011; 9: 195-208.

75. Hutton RA, Warrell DA. Action of Snake Venom Components on the Haemostatic System. Blood Rev. 1993; 7: $176-189$.

76. Vaiyapuri S, Harrison RA, Bicknell AB, Gibbins JM, Hutchinson G. Purification and Functional Characterisation of Rhinocerase, a Novel Serine Protease from the Venom of Bitis gabonica rhinoceros. PloS One. 2010; 5: e9687.

77. Barros L, Soares A, Costa F, Rodrigues V, Fuly A, et al. Biochemical and Biological Evaluation of Gyroxin Isolated from Crotalus durissus terrificus Venom. J Venom Anim Toxins incl Trop Dis. 2011; 17: 23-33.

78. Costa C, Belchor M, Rodrigues C, Toyama D, de Oliveira $\mathrm{M}$, et al. Edema Induced by a Crotalus durissus terrificus Venom Serine Protease Cdtsp 2. Involves the PAR Pathway and PKC and PLC Activation. IJMS. 2018; 19: 2405.

79. Sousa IDL, Barbosa AR, Salvador GHM, Frihling BEF, Santa-Rita PH, et al. Secondary Hemostasis Studies of Crude 
Prime Archives in Immunology: $2^{\text {nd }}$ Edition

Venom and Isolated Proteins from the Snake Crotalus durissus terrificus. Int J Biol Macromol. 2019; 131: 127133.

80. Barros LC, Ferreira RS, Barraviera SRCS, Stolf HO, Thomazini-Santos IA, et al. A New Fibrin Sealant From Crotalus durissus terrificus Venom: Applications in Medicine. J Toxicol Environ Health Part B. 2009; 12: 553571.

81. Boldrini-França J, Santos Rodrigues R, Santos-Silva LK, de Souza DLN, Gomes MSR, et al. Expression of a New Serine Protease from Crotalus durissus collilineatus Venom in Pichia pastoris and Functional Comparison With the Native Enzyme. Appl Microbiol Biotechnol. 2015; 99: 9971-9986.

82. Clemetson KJ. Snaclecs Snake C-type Lectins; that Inhibit or Activate Platelets by Binding to Receptors. Toxicon. 2010; 56: $1236-1246$.

83. Morita T. Structures and Functions of Snake Venom CLPs C-Type Lectin-Like Proteins; with Anticoagulant-, Procoagulant-, and Platelet-Modulating Activities. Toxicon. 2005; 45: 1099-1114.

84. Eble J. Structurally Robust and Functionally Highly Versatile - C-Type Lectin -Related; Proteins in Snake Venoms. Toxins. 2019; 11: 136.

85. Polgár J, Clemetson JM, Kehrel BE, Wiedemann M, Magnenat EM, et al. Platelet Activation and Signal Transduction by Convulxin, A C-type Lectin From Crotalus durissus terrificus Tropical Rattlesnake; Venom Via the P62/GPVI Collagen Receptor. J Biol Chem. 1997; 272: 13576-13583.

86. Rádis-Baptista G, Moreno FBMB, de Lima Nogueira L, Martins AMC, de Oliveira Toyama D, et al. Crotacetin, a Novel Snake Venom C-Type Lectin Homolog of Convulxin, Exhibits an Unpredictable Antimicrobial Activity. CBB. 2006; 44: 412-423.

87. Fox JW, Serrano SMT. Timeline of Key Events in Snake Venom Metalloproteinase Research. J Proteomics. 2009; 72: 200-209. 
Prime Archives in Immunology: $2^{\text {nd }}$ Edition

88. Gutiérrez JM, Rucavado A. Snake Venom Metalloproteinases: Their Role in the Pathogenesis of Local Tissue Damage. Biochimie. 2000; 82: 841-850.

89. Fox JW, Serrano SMT. Insights into and Speculations about Snake Venom Metalloproteinase SVMP; Synthesis, Folding and Disulfide Bond Formation and their Contribution to Venom Complexity. FEBS J. 2008; 275: 3016-3030.

90. Olaoba OT, dos Santos PK, Selistre-de-Araujo HS, Ferreira de Souza DH. Snake Venom Metalloproteinases Svmps: A Structure-Function Update. Toxicon: X. 2020; 7: 100052.

91. Herrera C, Escalante T, Voisin M-B, Rucavado A, Morazán $\mathrm{D}$, et al. Tissue Localization and Extracellular Matrix Degradation by PI, PII and PIII Snake Venom Metalloproteinases: Clues on the Mechanisms of VenomInduced Hemorrhage. PloS Negl Trop Dis. 2015; 9: e0003731.

92. Meléndez-Martínez D, Plenge-Tellechea LF, Gatica-Colima A, Cruz-Pérez MS, Aguilar-Yáñez JM, et al. Functional Mining of the Crotalus spp. Venom Protease Repertoire Reveals Potential for Chronic Wound Therapeutics. Molecules. 2020; 25: 1-19.

93. Williams HF, Mellows BA, Mitchell R, Sfyri P, Layfield HJ, et al. Mechanisms Underpinning the Permanent Muscle Damage Induced by Snake Venom Metalloprotease. PloS Negl Trop Dis. 2019; 13: e0007041.

94. Schenberg S. Geographical Pattern of Crotamine Distribution in the Same Rattlesnake Subspecies. Science. 1959; 129: 1361-1363.

95. Oguiura N, Boni-Mitake M, Rádis-Baptista G. New View on Crotamine, a Small Basic Polypeptide Myotoxin From South American Rattlesnake Venom. Toxicon. 2005; 46: 363-370.

96. Lima SC, Porta LC, Lima ÁC, Campeiro JD, Meurer Y, et al. Pharmacological Characterization of Crotamine Effects on Mice Hind Limb Paralysis Employing both Ex Vivo and In Vivo Assays: Insights into the Involvement of VoltageGated Ion Channels in the Crotamine Action on Skeletal Muscles. PloS Negl Trop Dis. 2018; 12: e0006700.

97. Batista da Cunha D, Pupo Silvestrini AV, Gomes da Silva AC, Maria de Paula Estevam D, Pollettini FL, et al. 
Prime Archives in Immunology: $2^{\text {nd }}$ Edition

Mechanistic Insights into Functional Characteristics of Native Crotamine. Toxicon. 2018; 146: 1-12.

98. Graham RLJ, Graham C, McClean S, Chen T, O'Rourke M, et al. Identification and Functional Analysis of a Novel Bradykinin Inhibitory Peptide in the Venoms of New World Crotalinae Pit Vipers. Biochem Biophys Res Commun. 2005; 338: 1587-1592.

99. Siltari A, Korpela R, Vapaatalo H. Bradykinin-Induced Vasodilatation: Role of Age, ACE1-inhibitory Peptide, Masand Bradykinin Receptors. Peptides. 2016; 85: 46-55.

100. Guo C, Liu S, Yao Y, Zhang Q, Sun M-Z. Past Decade Study of Snake Venom L-amino Acid Oxidase. Toxicon. 2012; 60: 302-311.

101. Du X-Y, Clemetson KJ. Snake Venom L-Amino Acid Oxidases. Toxicon. 2002; 40: 659-665.

102. Fox JW. A Brief Review of the Scientific History of Several Lesser-Known Snake Venom Proteins: L-Amino Acid Oxidases, Hyaluronidases and Phosphodiesterases. Toxicon. 2013; 62: 75-82.

103. Abdelkafi-Koubaa Z, Jebali J, Othman H, Morjen M, Aissa I, et al. A Thermoactive L-amino Acid Oxidase from Cerastes Cerastes Snake Venom: Purification, Biochemical and Molecular Characterization. Toxicon. 2014; 89: 32-44.

104. Wiezel GA, Rustiguel JK, Morgenstern D, Zoccal KF, Faccioli LH, et al. Insights into the Structure, Function and Stability of bordonein-L, the First L-amino Acid Oxidase from Crotalus durissus terrificus Snake Venom. Biochimie. 2019; 163: 33-49.

105. Toyama MH, Toyama DO, Passero LFD, Laurenti MD, Corbett CE, et al. Isolation of a New L-amino Acid Oxidase from Crotalus durissus cascavella Venom. Toxicon. 2006; 47: 47-57.

106. Vargas LJ, Quintana JC, Pereañez JA, Núñez V, Sanz L, et al. Cloning and Characterization of an Antibacterial Lamino Acid Oxidase from Crotalus durissus cumanensis Venom. Toxicon. 2013; 64: 1-11.

107. Teixeira TL, Oliveira Silva VA, da Cunha DB, Polettini FL, Thomaz CD, et al. Isolation, Characterization and Screening of the In Vitro Cytotoxic Activity of a Novel Lamino Acid Oxidase Laaocdt; from Crotalus durissus 
Prime Archives in Immunology: $2^{\text {nd }}$ Edition

terrificus Venom on Human Cancer Cell Lines. Toxicon. 2016; 119: 203-217.

108. Rodrigues RS, da Silva JF, Boldrini França J, Fonseca FPP, Otaviano AR, et al. Structural and Functional Properties of Bp-LAAO, A New L-amino Acid Oxidase Isolated From Bothrops pauloensis Snake Venom. Biochimie. 2009; 91: 490-501.

109. França SC, Kashima S, Roberto PG, Marins M, Ticli FK, et al. Molecular Approaches for Structural Characterization of Bothrops L-Amino Acid Oxidases with Antiprotozoal Activity: cDNA Cloning, Comparative Sequence Analysis, and Molecular Modeling. Biochem Biophys Res Commun. 2007; 355: 302-306.

110. Oliveira IS, Manzini RV, Ferreira IG, Cardoso IA, Bordon KCF, et al. Cell Migration Inhibition Activity of a Non-RGD Disintegrin from Crotalus durissus collilineatus Venom. J Venom Anim Toxins Incl Trop Dis. 2018; 24: 28.

111. Bordon KCF, Perino MG, Giglio JR, Arantes EC. Isolation, Enzymatic Characterization and Antiedematogenic Activity of the First Reported Rattlesnake Hyaluronidase from Crotalus durissus terrificus Venom. Biochimie. 2012; 94: 2740-2748.

112. Dos-Santos MC, Assis EB, Moreira TD, Pinheiro J, Fortes-Dias CL. Individual Venom Variability in Crotalus durissus ruruima Snakes, a Subspecies of Crotalus durissus from the Amazonian Region. Toxicon. 2005; 46: 958-961.

113. Santos HLR, Sousa JDB, Alcântara JA, Sachett JAG, Boas T, et al. Rattlesnakes Bites in the Brazilian Amazon: Clinical Epidemiology, Spatial Distribution and Ecological Determinants. Acta Trop. 2019; 191: 69-76.

114. Monteiro WM, Farias AS, Val F, Neto AVS, Sachett A, et al. Providing Antivenom Treatment Access to All Brazilian Amazon Indigenous Areas: 'Every Life has Equal Value'. Toxins. 2020; 12: 772.

115. Mendonça-da-Silva I, Magela Tavares A, Sachett J, Sardinha JF, Zaparolli L, et al. Safety and Efficacy of a Freeze-Dried Trivalent Antivenom for Snakebites in the Brazilian Amazon: An Open Randomized Controlled Phase IIb Clinical Trial. PloS Negl Trop Dis. 2017; 11: e0006068. 
Prime Archives in Immunology: $2^{\text {nd }}$ Edition

116. Bucaretchi F, Herrera SRF, Hyslop S, Baracat ECE, Vieira RJ. Snakebites by Crotalus durissus ssp in Children in Campinas, São Paulo, Brazil. Rev do Inst Med Trop São Paulo. 2002; 44: 133-138.

117. Cupo P, Azevedo-Marques MM, Hering SE. Acidente Crotálico na Infância: Aspectos Clínicos, Laboratoriais, Epidemiológicos e Abordagem Terapêutica. Rev da Soc Bras Med Trop. 1991; 24: 87-96.

118. Jorge MT, Ribeiro LA. Epidemiologia e Quadro Clínico do Acidente por Cascavel Sul-Americana Crotalus durissus. Rev do Inst Med Trop São Paulo. 1992; 34: 347-354.

119. Nishioka SA, Jorge MT, Silveira PVP, Ribeiro LA. South American Rattlesnake Bite and Soft-Tissue Infection: Report of a Case. Rev da Soc Bras Med Trop. 2000; 33: 401-402.

120. Bucaretchi F, De Capitani EM, Hyslop S, Mello SM, Fernandes CB, et al. Compartment Syndrome after South American Rattlesnake Crotalus durissus terrificus; Envenomation. Clin Toxicol Phila. 2014; 52: 639-641.

121. Carvalho LH, Teixeira LF, Zaqueo KD, Bastos JF, Nery NM, et al. Local and Systemic Effects Caused by Crotalus durissus terrificus, Crotalus durissus collilineatus, and Crotalus durissus cascavella Snake Venoms in Swiss Mice. Rev Soc Bras Med Trop. 2019; 52: e20180526.

122. Sartim MA, Souza COS, Diniz CRAF, da Fonseca VMB, Sousa LO, et al. Crotoxin-Induced Mice Lung Impairment: Role of Nicotinic Acetylcholine Receptors and COX-Derived Prostanoids. Biomolecules. 2020; 10: 794.

123. Azevedo-Marques M, Hering S, Cupo P. Acidente Crotálico. In: Animais Peçonhentos No Brasil. São Paulo: Sarvier. 2003; 108-115.

124. Silveira PV, Nishioka S de A. South American Rattlesnake Bite in a Brazilian Teaching Hospital. Clinical and Epidemiological Study of 87 Cases, with Analysis of Factors Predictive of Renal Failure. Trans R Soc Trop Med Hyg. 1992; 86: 562-564.

125. Pinho FMO, Zanetta DMT, Burdmann EA. Acute Renal Failure after Crotalus durissus Snakebite: A Prospective Survey on 100 Patients. Kidney Int. 2005; 67: 659-667. 
Prime Archives in Immunology: $2^{\text {nd }}$ Edition

126. Faro SML, Coutinho IJB, Gadelha MAC, Pardal PPO. Envenenamento Por Crotalus durissus marajoensis Em Muaná, Ilha de Marajó, Estado do Pará, Brasil. Rev PanAmazônica Saúde. 2020; 11: 1-6.

127. Sampaio SC, Hyslop S, Fontes MRM, Prado-Franceschi J, Zambelli VO, et al. Crotoxin: Novel Activities for a Classic $\beta$-Neurotoxin. Toxicon. 2010; 55: 1045-1060.

128. Lomonte B, Gutiérrez JM. Phospholipases $\mathrm{A}_{2}$ From Viperidae Snake Venoms: How do They Induce Skeletal Muscle Damage? Acta Chim Slov. 2011; 58: 647-659.

129. Martins AMC, Toyama MH, Havt A, Novello JC, Marangoni S, et al. Determination of Crotalus durissus cascavella Venom Components That Induce Renal Toxicity in Isolated Rat Kidneys. Toxicon. 2002; 40: 1165-1171.

130. Martins AMC, Monteiro HSA, Júnior EOG, Menezes DB, Fonteles MC. Effects of Crotalus durissus cascavella Venom in the Isolated Rat Kidney. Toxicon. 1998; 36: $1441-1450$.

131. Amora DN, Sousa TM, Martins AMC, Barbosa PSF, Magalhães MR, et al. Effects of Crotalus durissus collilineatus Venom in the Isolated Rat Kidney. Toxicon. 2006; 47: 260-264.

132. Monteiro HSA, da Silva IMSC, Martins AMC, Fonteles MC. Actions of Crotalus durissus terrificus Venom and Crotoxin on the Isolated Rat Kidney. Braz J Med Biol Res. 2001; 34: 1347-1352.

133. Petejova N, Martinek A. Acute Kidney Injury Due to Rhabdomyolysis and Renal Replacement Therapy: A Critical Review. Crit Care. 2014; 18: 224.

134. Martins AMC, Lima AAM, Toyama MH, Marangoni S, Fonteles MC, et al. Renal Effects of Supernatant from Macrophages Activated by Crotalus durissus cascavella Venom: The Role of Phospholipase $\mathrm{A}_{2}$ and Cyclooxygenase: Renal Effects of Crotalus Venom. Pharmacol Toxicol. 2003; 92: 14-20.

135. Martins AMC, Nobre ACL, Almeida AC, Bezerra G, Lima AAM, et al. Thalidomide and Pentoxifylline Block the Renal Effects of Supernatants of Macrophages Activated With Crotalus durissus cascavella Venom. Braz J Med Biol Res. 2004; 37: 1525-1530. 
Prime Archives in Immunology: $2^{\text {nd }}$ Edition

136. Bucaretchi F, De Capitani EM, Branco MM, Fernandes LCR, Hyslop S. Coagulopathy as the Main Systemic Manifestation After Envenoming by a Juvenile South American Rattlesnake Crotalus durissus terrificus;: Case Report. Clin Toxicol Phila. 2013; 51: 505-508.

137. Malaque CMS, Duayer IF, Santoro ML. Acute Kidney Injury Induced by Thrombotic Microangiopathy in Two Cases of Bothrops envenomation. Clin Toxicol. 2019; 57: 213-216.

138. Sano-Martins IS, Tomy SC, Campolina D, Dias MB, de Castro SCB, et al. Coagulopathy Following Lethal and Non Lethal Envenoming of Humans by the South American Rattlesnake Crotalus durissus; in Brazil. QJM: Int J Med. 2001; 94: 551-559.

139. Ministério da Saúde. Guia De Vigilância Em Saúde: [Recurso Eletrônico]. 3rd ed. Brasília: Ministério da Saúde. 2019.

140. Horton S, Augustin S. Activated Clotting Time Act. In: Monagle P, editor. Haemostasis Methods in Molecular Biology. Totowa : Humana Press. 2013; 155-167.

141. Gimenez BT, Cezarette GN, Bomfim A de S, Monteiro WM, Russo EM de S, et al. Role of Crotoxin in Coagulation:

Novel Insights into Anticoagulant Mechanisms and Impairment of Inflammation-Induced Coagulation. J Venom Anim Toxins incl Trop Dis. 2020; 26: e20200076.

142. Landucci ECT, Condino-Neto A, Perez AC, Hyslop S, Corrado AP, et al. Crotoxin Induces Aggregation of Human Washed Platelets. Toxicon. 1994; 32: 217-226.

143. Gutiérrez JM, Escalante T, Rucavado A, Herrera C. Hemorrhage Caused by Snake Venom Metalloproteinases: A Journey of Discovery and Understanding. Toxins. 2016; 8: 93.

144. Hernández M, Scannone H, Finol HJ, Pineda ME, Fernández I, et al. Alterations in the Ultrastructure of Cardiac Autonomic Nervous System Triggered by Crotoxin From Rattlesnake Crotalus durissus cumanensis; Venom. Exp Toxicol Pathol. 2007; 59: 129-137.

145. da Silva JAA, Spencer P, Camillo MA, de Lima VMF. Gyroxin and Its Biological Activity: Effects on CNS 
Prime Archives in Immunology: $2^{\text {nd }}$ Edition

Basement Membranes and Endothelium and ProteaseActivated Receptors. CMC. 2012; 19: 281-291.

146. Pardal PPO, Silva CLQ, Hoshino SSN, Pinheiro MFR. Acidente Por Cascavel Crotalus sp; Em Ponta de Pedras, Ilha do Marajó, Pará - Relato de Caso. Rev Paraense Med. 2007; 21: 69-73.

147. Pardal PPO, Pardal JSO, Castro LC, Cardoso BS, Sousa AMB, et al. Acidentes por Cascavel Crotalus durissus; no Estado do Pará. Rev Para Med. 2003; 17: 27-31.

148. Amaral CFS, Magalhães RA, Rezende NA. Comprometimento Respiratório Secundário a Acidente Ofídico Crotálico Crotalus durissus. Rev Inst Med Trop S Paulo. 1991; 33: 251-255.

149. Baum RA, Bronner J, Akpunonu PDS, Plott J, Bailey $\mathrm{AM}$, et al. Crotalus durissus terrificus Viperidae; Crotalinae; Envenomation: Respiratory Failure and Treatment With Antivipmyn TRI ${ }^{\circledR}$ Antivenom. Toxicon. 2019; 163: 32-35.

150. Souza AS, Sachett JAG, Alcântara JA, Freire M, Alecrim M das GC, et al. Snakebites as Cause of Deaths in the Western Brazilian Amazon: Why and Who Dies? Deaths From Snakebites in the Amazon. Toxicon. 2018; 145: 15-24.

151. Feitosa EL, Sampaio VS, Salinas JL, Queiroz AM, da Silva IM, et al. Older Age and Time to Medical Assistance are Associated with Severity and Mortality of Snakebites in the Brazilian Amazon: A Case-Control Study. PloS One. 2015; 10: e0132237.

152. Garnelo L, Wright R. Doença, Cura E Serviços De Saúde. Representações, Práticas e Demandas Baníwa. Cadernos Saúde Pública. 2001; 17: 273-284.

153. Ribeiro LA, Albuquerque MJ, Pires de Campos V, Katz G, Takaoka NY, et al. Óbitos por Serpentes Peçonhentas no Estado de São Paulo: Avaliação de 43 Casos, 1988/93. Rev da Assoc Méd Bras. 1998; 44: 312-318.

154. Frare BT, Silva Resende YK, Dornelas BC, Jorge MT, Souza Ricarte VA, et al. Clinical, Laboratory, and Therapeutic Aspects of Crotalus durissus South American Rattlesnake. Victims: A Literature Review. BioMed Res Int. 2019; 2019: 1-7.

155. Amaral CFS, Campolina D, Dias MB, Bueno CM, Rezende NA. Tourniquet Ineffectiveness to Reduce the 
Prime Archives in Immunology: $2^{\text {nd }}$ Edition

Severity of Envenoming after Crotalus durissus Snake Bite in Belo Horizonte, Minas Gerais, Brazil. Toxicon. 1998; 36: 805-808.

156. Teixeira-Araújo R, Castanheira P, Brazil-Más L, Pontes $\mathrm{F}$, de Araújo ML, et al. Antivenomics as a Tool to Improve the Neutralizing Capacity of the Crotalic Antivenom: A Study With Crotamine. J Venomous Anim Toxins Including Trop Dis. 2017; 23: 1-8.

157. Ministério da Saúde. Manual De Diagnóstico E Tratamento De Acidentes Por Animais Peçonhentos. Brasília: Ministério da Saúde. 2001.

158. Fan HW, Natal Vigilato MA, Augusto Pompei JC, Gutiérrez JM. En Representación de la Red de Laboratorios Públicos Productores de Antivenenos de América Latina RELAPA. Situación de los Laboratorios Públicos Productores de Antivenenos en América Latina. Rev Panamericana Salud Pública. 2019; 43: 1.

159. Saravia P, Rojas E, Arce V, Guevara C, López JC, et al. Geographic and Ontogenic Variability in the Venom of the Neotropical Rattlesnake Crotalus durissus:

Pathophysiological and Therapeutic Implications. Rev Biol Trop. 2002; 50: 337-346.

160. Segura Á, Herrera M, Reta Mares F, Jaime C, Sánchez $\mathrm{A}$, et al. Proteomic, Toxicological and Immunogenic Characterization of Mexican West-Coast Rattlesnake Crotalus basiliscus; Venom and its Immunological Relatedness with the Venom of Central American Rattlesnake Crotalus simus;. J Proteomics. 2017; 158: 6272.

161. Fan HW, Monteiro WM. History and Perspectives on How to Ensure Antivenom Accessibility in the Most Remote Areas in Brazil. Toxicon. 2018; 151: 15-23.

162. Ministério da Saúde. Distrito Sanitário Especial Indígena - Leste de Roraima. em Atenção ao Ofício 0017945740. onde o Instituto Insikiran/UFRR Solicita de Informações sobre o Ofidismo e Outras Informações Complementares, Encaminho para Ciência e Providências as Seguintes Respostas em Conformidades Numeral com as Respectivas Perguntas. Boa Vista, Roraima. Ministério da Saúde. 2020. 
Prime Archives in Immunology: $2^{\text {nd }}$ Edition

163. Magalhães SFV, Peixoto HM, de Almeida Gonçalves Sachett J, Oliveira SS, Alves EC, et al. Snakebite Envenomation in the Brazilian Amazon: A Cost-of-Illness Study. Trans R Soc Trop Med Hyg. 2020; 114: 635-642.

164. Bux Z, Persaud S. Guyana Secures Snake Bite AntiVenom -as Doctors Receive Snake Bite Management Training, in: Kaieteur News. 2019. Available online at: https://www.kaieteurnewsonline.com/2019/06/16/guyanasecures-snake-bite-anti-venom-as-doctors-receive-snakebite-management-training/

165. Resiere D, Monteiro W, Houcke S, Pujo JM, Mathien C, et al. Bothrops Snakebite Envenomings in the Amazon Region. Curr Trop Med Rep. 2020; 7: 48-60.

166. Pucca MB, Franco MVS, Medeiros JM, Oliveira IS, Ahmadi S, et al. Chronic Kidney Failure Following Lancehead Bite Envenoming: A Clinical Report from the Amazon Region. J Venom Anim Toxins incl Trop Dis. 2020; 26: $1-8$.

167. Gutiérrez JM, Lewin MR, Williams DJ, Lomonte B. Varespladib LY315920; and Methyl Varespladib Ly333013; Abrogate or Delay Lethality Induced by Presynaptically Acting Neurotoxic Snake Venoms. Toxins. 2020; 12: 131.

168. Laustsen AH, Gutiérrez JM, Knudsen C, Johansen KH, Bermúdez-Méndez E, et al. Pros and Cons of Different Therapeutic Antibody Formats for Recombinant Antivenom Development. Toxicon. 2018; 146: 151-175.

169. Hawgood BJ. Pioneers of Anti-Venomous Serotherapy: Dr Vital Brazil 1865-1950;. Toxicon. 1992; 30: 573-579.

170. van Eyk HG, Terhorst $C$, de Vijlder MMA. Fragmentation of Human $\operatorname{IgG}$ Globulin With Papain, Trypsin and Pepsin. Clin Chim Acta. 1967; 16: 429-431.

171. Abbas AK, Lichtman AH, Pillai S, Baker DL, Baker A. Cellular and Molecular Immunology. Ninth edition. Philadelphia: Elsevier. 2018.

172. Farrar HC, Grayham T, Bolden B, Vyas D, Graham J, et al. The Use and Tolerability of Crotalidae Polyvalent Immune FAB Ovine; in Pediatric Envenomations. Clin Pediatr Phila. 2012; 51: 945-949.

173. Krifi MN, El Ayeb M, Dellagi K. The Improvement and Standardization of Antivenom Production in Developing 
Prime Archives in Immunology: $2^{\text {nd }}$ Edition

Countries: Comparing Antivenom Quality, Therapeutical Efficiency, and Cost. J Venomous Anim Toxins. 1999; 5: $128-41$.

174. Squaiella-Baptistão CC, Sant'Anna OA, Marcelino JR, Tambourgi DV. The History of Antivenoms Development: Beyond Calmette and Vital Brazil. Toxicon. 2018; 150: 8695.

175. Bermúdez-Méndez E, Fuglsang-Madsen A, Føns S, Lomonte B, Gutiérrez JM, et al. Innovative Immunization Strategies for Antivenom Development. Toxins Basel. 2018; 10: $1-37$.

176. Pucca MB, Cerni FA, Janke R, Bermúdez-Méndez E, Ledsgaard L, et al. History of Envenoming Therapy and Current Perspectives. Front Immunol. 2019; 10: 1-13.

177. Ahmadi S, Pucca MB, Jürgensen JA, Janke R, Ledsgaard L, et al. An In Vitro Methodology for Discovering Broadly-Neutralizing Monoclonal Antibodies. Sci Rep. 2020; 10: 10765.

178. Pucca MB, Cerni FA, Peigneur S, Arantes EC, Tytgat J, et al. Serrumab: A Novel Human Single Chain-Fragment Antibody with Multiple Scorpion Toxin-Neutralizing Capacities. J Immunotoxicol. 2014; 11: 133-140.

179. Pessenda G, Silva LC, Campos LB, Pacello EM, Pucca $\mathrm{MB}$, et al. Human scFv Antibodies Afribumabs; Against Africanized Bee Venom: Advances in Melittin Recognition. Toxicon. 2016; 112: 59-67.

180. Campos LB, Pucca MB, Silva LC, Pessenda G, Filardi BA, et al. Identification of Cross-Reactive Human SingleChain Variable Fragments Against Phospholipases $\mathrm{A}_{2}$ from Lachesis muta and Bothrops spp Venoms. Toxicon. 2020; 184: 116-121.

181. Føns S, Ledsgaard L, Nikolaev MV, Vassilevski AA, Sørensen CV, et al. Discovery of a Recombinant Human Monoclonal Immunoglobulin $\mathrm{G}$ Antibody Against $\alpha$ Latrotoxin from the Mediterranean Black Widow Spider Latrodectus tredecimguttatus. Front Immunol. 2020; 1: 1-9.

182. McCafferty J, Griffiths AD, Winter G, Chiswell DJ. Phage Antibodies: Filamentous Phage Displaying Antibody Variable Domains. Nature. 1990; 348: 552-554. 
Prime Archives in Immunology: $2^{\text {nd }}$ Edition

183. Meng J, John TR, Kaiser II. Specificity and Binding Affinity of an Anti-Crotoxin Combinatorial Antibody Selected From a Phage-Displayed Library. Biochem Pharmacol. 1995; 50: 1969-1977.

184. Lafaye P, Choumet V, Demangel C, Bon C, Mazié JC. Biologically Active Human Anti-Crotoxin scFv Isolated from a Semi-Synthetic Phage Library. Immunotechnology. 1997; 3: 117-125.

185. Oliveira JG, Soares SG, Soares AM, Giglio JR, Teixeira JE, et al. Expression of Human Recombinant Antibody Fragments Capable of Partially Inhibiting the Phospholypase Activity of Crotalus durissus terrificus Venom. Basic Clin Pharmacol Toxicol. 2009; 105: 84-91.

186. Silva LC, Pucca MB, Pessenda G, Campos LB, Martinez EZ, et al. Discovery of Human scFvs That Cross-Neutralize the Toxic Effects of B. jararacussu and C. d. terrificus Venoms. Acta Trop. 2018; 177: 66-73.

187. Titus JK, Kay MK, Glaser CJJ, Hwang YY. Application of Phage Display for the Development of a Novel Inhibitor of $\mathrm{PLA}_{2}$ Activity in Western Cottonmouth Venom. J Venom Res. 2017; 8: 19-24.

188. Laustsen AH, Lohse B, Lomonte B, Engmark M, Gutiérrez JM. Selecting Key Toxins for Focused Development of Elapid Snake Antivenoms and Inhibitors Guided by a Toxicity Score. Toxicon. 2015; 104: 43-45.

189. Laustsen AH. Guiding Recombinant Antivenom Development by Omics Technologies. N Biotechnol. 2018; 45: 19-27.

190. Laustsen AH, Engmark M, Clouser C, Timberlake S, Vigneault $\mathrm{F}$, et al. Exploration of Immunoglobulin Transcriptomes from Mice Immunized With Three-Finger Toxins and Phospholipases $\mathrm{A}_{2}$ From the Central American Coral Snake, Micrurus nigrocinctus. PeerJ. 2017; 5: e2924.

191. Knudsen C, Ledsgaard L, Dehli RI, Ahmadi S, Sørensen $\mathrm{CV}$, et al. Engineering and Design Considerations for NextGeneration Snakebite Antivenoms. Toxicon. 2019; 167: 6775.

192. Laustsen AH. Recombinant Antivenoms [Phd Thesis]. University of Copenhagen, Denmark. 2016. 
Prime Archives in Immunology: $2^{\text {nd }}$ Edition

193. Kini RM, Sidhu SS, Laustsen AH. Biosynthetic Oligoclonal Antivenom [BOA] for Snakebite and NextGeneration Treatments for Snakebite Victims. Toxins. 2018; 10: $1-10$. 